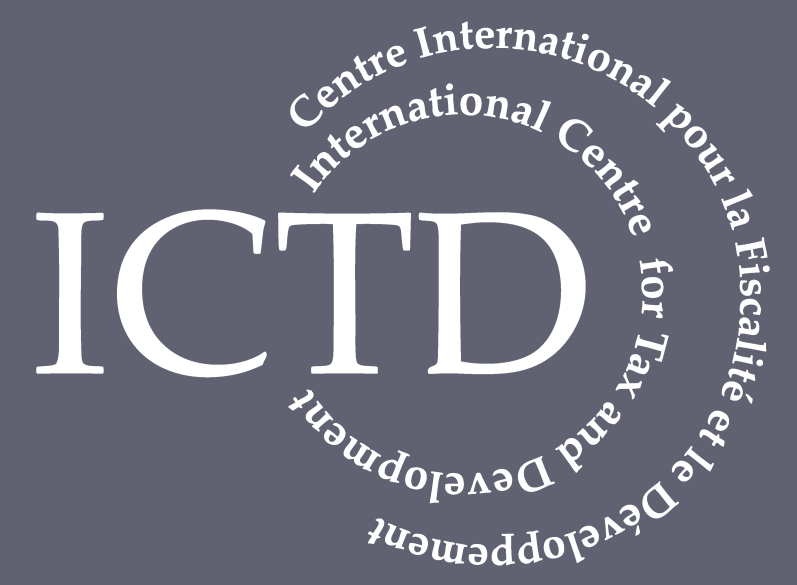

Working Paper 74

Norms, Networks, Power, and Control:

Understanding Informal Payments and

Brokerage in Cross-Border Trade in

Sierra Leone

Vanessa van den Boogaard, Wilson Prichard, and Samuel Jibao

February 2018

BILL \& MELINDA

GATES foundation 
ICTD Working Paper 74

Norms, Networks, Power, and Control: Understanding Informal Payments and Brokerage in Cross-Border Trade in Sierra Leone

Vanessa van den Boogaard, Wilson Prichard and Samuel Jibao February 2018 
Norms, Networks, Power, and Control: Understanding Informal Payments and Brokerage in Cross-Border Trade in Sierra Leone Vanessa van den Boogaard, Samuel Jibao and Wilson Prichard

ICTD Working Paper 74

First published by the Institute of Development Studies in February 2018

(C) Institute of Development Studies 2018

ISBN: 978-1-78118-428-8

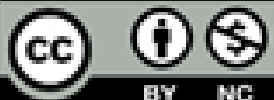

This is an Open Access paper distributed under the terms of the Creative Commons Attribution Non Commercial 4.0 International license, which permits downloading and sharing provided the original authors and source are credited - but the work is not used for commercial purposes. http://creativecommons.org/licenses/by-nc/4.0/legalcode

\section{Available from:}

The International Centre for Tax and Development at the Institute of Development Studies, Brighton BN1 9RE, UK

Tel: +44(0) 127360626

Email: info@ictd.ac.uk

Web: www.ictd/en/publications

IDS is a charitable company limited by guarantee and registered in England

Charity Registration Number 306371

Charitable Company Number 877338 


\title{
Norms, Networks, Power, and Control: Understanding Informal Payments and Brokerage in Cross-Border Trade in Sierra Leone
}

\author{
Vanessa van den Boogaard, Samuel Jibao and Wilson Prichard
}

\section{Summary}

Recent research has cast light on the variety of informal payments and practices that govern the day-to-day interactions between traders and customs agents at border posts in lowincome countries. Building on this literature, this paper draws on survey and qualitative evidence in an effort to explore which groups are most advantaged and disadvantaged by the largely informal processes and norms governing cross-border trade. We find that understanding variation in strategies and outcomes across traders can only be effectively understood with reference to the importance of norms, networks, power, and the logic of control.

Keywords: taxation, customs, informality, trade, Africa; cross-border trade

Samuel Jibao is Director and CEO of the Centre for Economic Research and Capacity Building, based in Freetown. He previously worked for the Sierra Leonean National Revenue Authority.

Vanessa van den Boogaard is a doctoral candidate in Political Science at the University of Toronto. She is a currently a Fellow at the Institute of Municipal Finance and Governance.

Wilson Prichard is an Associate Professor jointly appointed to the Department of Political Science and the Munk School of Global Affairs at the University of Toronto. He is also a Research Fellow at the Institute of Development Studies at the University of Sussex, and a Research Director of the International Centre for Tax and Development. 


\section{Contents}

Summary 3

Acknowledgements $\quad 5$

$\begin{array}{ll}\text { Introduction } & 6\end{array}$

$1 \quad$ Informality and cross-border trade $\quad 7$

1.1 Causes of the prevalence of informality in cross-border trade 8

$\begin{array}{ll}1.2 & \text { Winners and losers of pervasive informality } \\ \end{array}$

$2 \quad$ The day-to-day reality of cross-border trade in Sierra Leone 11

3 What explains the prevalence of unrecorded taxation and informal brokerage in cross-border trade?

$\begin{array}{llr}3.1 & \text { Profit } & 13 \\ 3.2 & \text { Power } & 15 \\ 3.3 & \text { Networks } & 16 \\ 3.4 & \text { Protest } & 18 \\ 3.5 & \text { Institutionalisation } & 19\end{array}$

$4 \quad$ Who benefits and who loses from institutionalised informality? 20

5 Conclusion $\quad 24$

$\begin{array}{lr}\text { References } & 26\end{array}$

Tables

Table 1

Table 2

Table 3

Table 4

Table 5

Table 6

Table 7

Table 8

Table 9

Table 10

Prevalence of informal practices 13

Power and informality 16

Networks and informality 17

Correlation between public service satisfaction and informal practices 18

Distances and travel times from border posts 19

Prevalence of informal practices by border post 19

Social power and treatment at the border $\quad 21$

Networks and treatment at the border $\quad 21$

Control and treatment at the border 22

Treatment at the border $\quad 22$

Table $11 \quad$ Marginal effects of independent variables 23

Figure

Figure 1 Reasons for engaging in informality 


\section{Acknowledgements}

Special thanks to Rogers Amara, Soko Kai-Samba, Thomas Johnny, Moses Sellu, Joseph Moore, Julia Lahai, Mbatilo Kamara, and Baindu Ngaujah for invaluable research support.

We extend our thanks to participants of the 2015 World Customs Organization PICARD conference and to two anonymous reviewers for valuable insights and advice. 


\section{Introduction}

In recent years, there has been growing interest in research capturing the dynamics of 'real' governance in low-income and fragile contexts. Governance practices in peripheral regions of low-income countries often diverge dramatically from statutory rules, with actual governance often representing a hybrid of formal rules and informal practices that are often highly normalised and widely accepted. ${ }^{1}$ Any understanding of the prospects for institutional or policy reform in these areas needs to begin from a clear understanding of these realities.

Several recent studies have focused on these informal governance practices in the context of cross-border trade and the implications for state authority in border regions, often referred to as 'peripheral' or 'liminal' spaces in relation to the state. ${ }^{2}$ This body of research, in addition to providing in-depth insights into a broad range of border practices and institutions, has demonstrated the ways in which everyday economic practices fail to correspond to the 'image' or the 'idea' of the state, ${ }^{3}$ but rather result in 'practical norms' that differ from official rules and regulations. ${ }^{4}$

Much of this literature focuses on informal cross-border trade writ large, including unrecorded trade of licit goods involving the evasion of customs duties and regulations. ${ }^{5}$ This paper draws on the rich insights offered from this broader body of literature in order to focus on two comparatively discrete questions to better understand the nature of informal payments that are made by cross-border traders through formal trade routes, and the nature of traders' engagement of informal brokers, known in Krio as chata men. ${ }^{6}$ First, what explains the prevalence of informal payments and informal brokers at border crossings? Existing research offers a wide variety of explanations: economic rationality, the absence of trust in the state, the exercise of power by predatory state agents and the outcomes of information asymmetries, and the role of ethnic, social, or kinship networks. Second, who benefits and who loses from pervasive informality? Again, the literature offers a variety of potential hypotheses, as groups may be disadvantaged based on their relative political and economic position, their ethnic or political identities, or the strength of their social, economic or political networks. Exploring these alternative explanations has important implications for understanding the foundations of local governance in border transactions, the nature of state-society relations in peripheral areas, and the potential for reform that is more aligned with local realities.

To address these questions, we investigate trader experiences at the two most important land borders in Sierra Leone: Gbalamuya, on the northern border with Guinea, and Gendema (Bo-Waterside), on the southern border with Liberia. These cases offer relevant variation in terms of the volume and type of trade, political and ethnic identities, and the relative degree of remoteness from the central state.

We use a mixed methods approach for understanding economic activity in border regions where the 'complexity is best addressed by a multifaceted approach'. ${ }^{7}$ We combine a relatively small survey of traders with focus groups with both traders and chata men and indepth interviews with key stakeholders and border officials. ${ }^{8}$ The greatest barrier to research

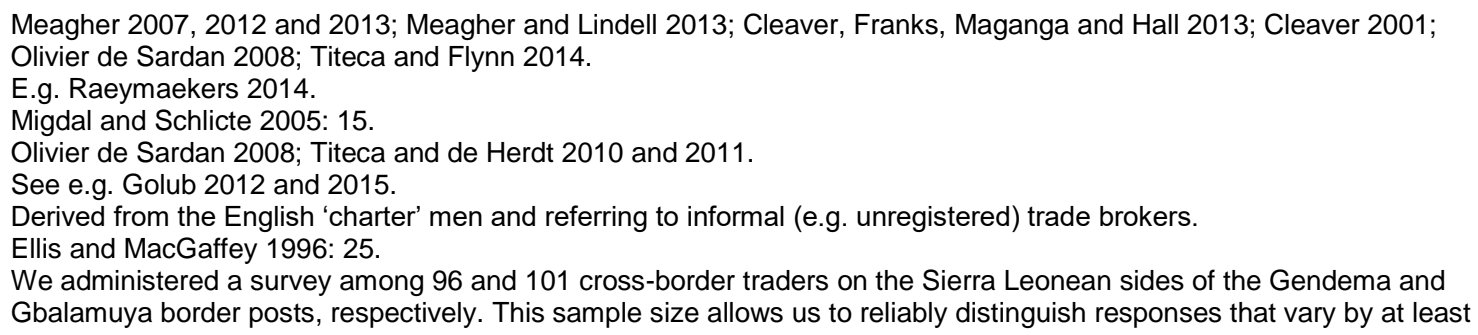


of this kind lies in being able to secure credible responses from traders and officials; we have confidence in our results for two primary reasons: coherence between information gathered through different methods, and the fact that we have been able to draw on trusting and respectful existing relationships between the local research team and research participants. ${ }^{9}$

Seeking to disentangle alternative explanations of the prevalence and nature of informal payments does not point toward some explanations that are 'right', and others than are 'wrong'. Instead, it underlines the need for a highly contextualised understanding of the dynamics of informal border practices. Individual traders do not face a black and white decision between 'formality' and 'informality'; indeed, informal practices are sometimes intertwined and indistinguishable from formal ones. ${ }^{10}$ Instead, the systems governing informal payments in cross-border trade are inescapable, highly normalised, and sometimes institutionalised, with individuals correspondingly facing decisions not about whether to engage in these practices, but in how best to navigate these systems given their needs, constraints, and resources. In constructing a more nuanced understanding of the drivers and outcomes of informality, the roles of power dynamics, personal relationships, and of the logic of control emerge particularly clearly. The availability of local networks and links to border officials plays a particularly important role in shaping both strategies and outcomes. Meanwhile, those who are organised into trade associations or who engage in informal border management committees at the community level face the highest costs of informality, suggesting that the local system of informal governance is not merely economic, but serves a localised political role.

We begin with a brief review of the literature, highlighting extant explanations of the pervasiveness of informal payments and brokerage in cross-border trade. We then provide a brief account of the functioning of customs operations at the two case border posts, before exploring the drivers of informal payments and brokerage, and the question of who wins and who loses from pervasive informality.

\section{Informality and cross-border trade}

Recent research has focused on capturing the ground-level reality of governance in lowincome and fragile contexts, with a subset of authors focusing on these interactions in border regions. As noted, this literature tends to focus on a broad set of informal practices and institutions within cross-border trade, including informal cross-border trade or smuggling, broader practices of brokerage, credit systems, and warehousing. Though our focus is much narrower - informal payments and informal brokerage within formal cross-border trade routes - the literature's insights into informal practices and governance are particularly valuable. Indeed, the foundational understanding that informal governance practices should be understood 'not as an absence of regulation, but as alternative forms of regulation operating below and beyond the framework of the state' helps to guide our own exploration of

+/- 10 per cent. Participants were randomly selected to the extent that this was possible, though random selection methods were subject to realities on the ground. Most notably, it was difficult to interview traders who were crossing the border very quickly, while traders were consistently willing to be interviewed if they were waiting in line, waiting for clearing agents, or if they remained in the border town overnight.

9 Samuel Jibao, who led the data gathering, is the former Director of Research for the National Revenue Agency in Sierra Leone and has since established an independent research institute. While it is possible to imagine that his former position could have made respondents reluctant to divulge 'sensitive' information, in practice his reputation for independence and honesty led respondents to be much more open once they knew of his involvement, while it also allowed for brokering frank discussion with senior government officials and notables in local communities.

10 Indeed, the literature on 'real' governance practices has included substantial debate about the term 'informal', centring both on what is meant by 'informal' and whether this term is appropriate at all in a context in which the so-called 'informal' is, in fact, widely accepted and normalised, while being highly integrated with the 'formal' (Meagher 1990, 2005; Roitman 1990, 2005; Cantens 2012; Hart 2005; Klein 1999). Throughout our discussion, we recognise the importance of this definitional debate, using the term 'informal' in a relatively straightforward and value-free manner, simply to refer to processes that are outside of statutory legal frameworks. 
informality within formal channels of trade. ${ }^{11}$ Informal practices more broadly often represent a complexity 'of negotiation, contestation and bricolage'12 among a multiplicity of state and non-state actors. Through these processes state institutions and public authority are sustained, contested, and/or remade. ${ }^{13}$ By understanding informal payments as reflecting governance arrangements that are both contested and often highly normalised and interactive with formal institutions, this literature thus creates space for a deeper understanding of the prevalence of informal practices and payments within border economies.

\subsection{Causes of the prevalence of informality in cross-border trade}

The literature presents four primary explanations for informality within cross-border trade: economic rationality, lack of trust in the state, power dynamics, and the strength of ethnic, social, religious, or kinship networks. We consider each in turn.

First, the most intuitive explanation for pervasive informality lies in economic rationality, and an assessment of the costs and benefits of formal versus informal economic activity, ${ }^{14}$ with traders engaging in informal practices in order to avoid higher taxes and bypass costly bureaucratic processes and non-tariff barriers to trade. ${ }^{15}$ This perspective thus sees informality as a 'source of economic freedom and empowerment' for economically marginalised segments of the population. ${ }^{16}$ In these contexts, informal economic activity is thought to be a more flexible, efficient and financially advantageous alternative to formal regulations, amounting to, as Klitgaard says of corruption, 'a crime of calculation, not passion'. ${ }^{17}$ Consistent with this perspective, several studies of informality in cross-border trade highlight the roles of uncoordinated trade and economic policies (e.g. import protection policies, subsidies, price controls, exchange rate misalignments) and high formal tariffs and taxes in influencing traders' decisions to engage in informal practices. ${ }^{18}$ These studies also point to other direct and indirect transaction costs that can be associated with formal trade, and which make circumventing formal channels of trade more attractive, particularly for small-scale traders. ${ }^{19}$

However, other studies make it clear that the reality is frequently more complex than this simple economic calculus. Most notably, in at least some cases the informal 'taxes' traders may pay in lieu of formal tariffs actually increase total payments, as a result of information and power asymmetries in the negotiation of informal tax rates, while also increasing the unpredictability of individual tax payments. ${ }^{20}$ Both problems can have a disproportionately

Meagher 2008 cited in Titeca and Flynn 2014: 78; see also Meagher 2011; Meagher and Lindell 2013.

Hagmann and Péclard 2010: 544

Titeca and Flynn 2014; Titeca 2012; Titeca and de Herdt 2011; Cleaver et al. 2013; Roitman 2004 and 2005; Lund 2006.

Benjamin and Mbaye 2012; Perry, Maloney, Arias, Fajnzylber, Mason and Saavedra 2007; Kanbur 2009; Djankov, Lieberman, Mukherjee and Nenova 2003; Loayza, Oviedo and Serven 2005; Johnson, Kaufmann, McMillan and Woodruff 2000

15 This follows rationalist perspectives of corruption, wherein corruption is viewed as 'instrumentally profitable' in the context of scarcity, disorder or an inequitable political environment. (Chabal and Daloz 1999: 106; see also Sindzingre 2002; Popkin 1979). Aidt describes this as 'efficient corruption', allowing individuals to work around misguided government policies and red tape. (Aidt 2003; see also Leff 1964; Lui 1985; Beck and Maher 1986). Roitman 2004: 32

Klitgaard 1988: 46

See e.g. Ackello-Ogutu and Echessah 1998; Macamo 1999; Levin and Widell 2007; Waseem 2013; Akinboade and Kinfack 2012; Gajigo and Hallward-Driemeier 2012; Ogra and Kundu 2011; Levy 2008; Golub 2015; Boone 1989; Berg 1985; Egg and Herrera 1998; Golub and Mbaye 2009; Oyejide, Ademola, Ogunkola, Bankole and Adwuyi 2008; Benjamin, Golub and Mbaye 2015; Ellis and MacGaffey 1996.

19 See e.g. Yoshino, Ngungi and Asebe 2012; OECD 2002; Lesser and Moisé-Leeman 2009; see also de Soto 1989 and 2000. For example, burdensome, non-transparent, inflexible, or otherwise inappropriate formal regulations, including technical regulations or health and phytosanitary standards, may induce traders and small businesses to develop alternative, non-statutory solutions that circumvent official channels and regulations to function (e.g. Lourenço-Lindel 2004; Ackello-Ogutu and Echessah 1997 and 1998; Minde and Nakhumwa 1998; Muwulya 2013; Brenton, Bashinge Bucekuderhwa, Hossein, Nagaki and Ntagoma 2012).

$20 \quad$ Amin and Hoppe 2013; Brenton et al. 2012; Yoshino et al. 2012; Titeca with Kimanuka 2012; OECD 2002. 
negative impact on small-scale traders. ${ }^{21}$ Meanwhile, research elsewhere indicates that reducing the costs of formality is frequently not sufficient to encourage informal firms to formalise. ${ }^{22}$ These more complex economic realities point toward the need to consider additional factors in explaining informal payments.

A second set of arguments has correspondingly focused on the possibility that traders may be more likely to engage in informality and circumvent formal trade channels and tax payments when they do not trust the state or view it as lacking legitimacy. ${ }^{23} \mathrm{~A}$ wide range of survey research has found that levels of trust in the state, satisfaction with public services and perceptions of fairness in the tax system can powerfully influence tax morale and compliance. ${ }^{24}$ Case studies of cross-border trade have echoed this message. ${ }^{25}$ As Cantens and Raballand describe, 'State representatives overvalue local populations' acceptance of the rule of law and consider the State's presence at borders as "natural", which does not necessarily chime with the local population's point of view. ${ }^{26}$ It is thus possible that traders may evade formal payments, as a form of political rebellion or protest against the state; a political 'weapon of the weak', and not simply a matter of economic survival. ${ }^{27}$

Again, however, existing research suggests greater complexity, with informality more generally understood as being opposed neither to the state or formal economic activity. As Roitman argues, the relationship between the formal and informal realms can be highly ambiguous, 'often reciprocal and complicitous as much as they are competitive and antagonistic'. ${ }^{28}$ Indeed, the 'practical norms' that develop around informal practices and payments are formed through continuous negotiation between formal and informal rules, involving a multiplicity of state and non-state actors. ${ }^{29}$

These first two explanations may be problematic as they assume that traders have autonomy to decide how they interact with, or disengage from, the formal rules. Recent studies emphasise, however, that in many contexts informal practices are critically shaped by local dynamics of power. ${ }^{30}$ There is often no option to opt out of informal payments or practices, particularly for marginalised segments of the population, who are likely to be particularly disadvantaged by the information and power asymmetries that characterise cross-border trade. ${ }^{31}$

Finally, social, economic, religious, or kinship networks and personal relationships may provide incentives to engage in informality. ${ }^{32}$ Ethnic, religious and kinship 'networks play a large role in organising the informal sector, and are particularly important in [informal crossborder trade] given that their populations often straddle national borders', ${ }^{33}$ themselves artificial, inherited, and porous concepts. ${ }^{34}$ Social or identity networks and relationships may

Amin and Hoppe 2013; Titeca with Kimanuka 2012; Schomerus and Titeca 2012; Tegera and Johnson 2007; Brenton et al. 2012.

La Porta and Shleifer 2014

Dzaka-Kikouta 2004; Ayadi, Benjamin, Bensassi and Raballand 2013; Tegara and Johnson 2007; Golub 2015.

Cummings, R., Martinez-Vazquez, J., McKee, M. and Torgler, B. 2005; Torgler 2004; Gibson and Hoffman 2005; Fjeldstad 2004; Fjeldstad and Semboja 2001; Ali, Fjeldstad and Sjursen 2013; Jibao and Prichard 2014; Addison and Murshed 2001; Smart 2013; Golub 2015.

Morini 2013; Muwulya 2013; Farré 2013; Ayadi et al. 2013; Titeca and Flynn 2014; Titeca and de Herdt 2010.

Cantens and Raballand 2017.

Scott 1987.

Roitman 2004: 131; see also Cantens 2012; Meagher 1990; Meagher and Lindell 2013; Roitman 1990 and 2005.

Titeca and Flynn 2014; Titeca 2012. This illustrates the analytical value of 'hybridity', which moves away from a statecentric framework, while at the same time emphasising the increasing lack of value in the concept of 'informality' itself (see e.g. Titeca and Flynn 2014; Hart 2005; Klein 1999; Meagher 2005; Roitman 2005; Cantens 2012; Portes 1994).

This parallels Olivier de Sardan's view of corruption as socially embedded within 'the logics of predatory authority'. Olivier de Sardan 1999.

Tegara and Johnson 2007; Titeca with Kimanuka 2012; Cantens 2012.

Médard 2002: 379; see also Brass and Krackhardt 2012: 355; Golub 2015.

Golub 2015; Golub and Hansen-Lewis 2012; Little 2005; Meagher 2010a; MacGaffey 1991; Igué and Solué 1992;

Hashim and Meagher 1999; Mahmood 2008; Kabamba 2013; Titeca 2009; Aker, Klein, O'Connell and Yang 2014

Golub 2015; see also Young 1994.
} 
encourage informality through the behavioural or social pressures of negotiation, exchange, redistribution, and reciprocity, ${ }^{35}$ or through the enabling of 'rational commercial organization and cooperation'. ${ }^{36}$ As described by Walther, the capacity of 'social actors' to cross the border 'depends very much on their social network, in particular the informal ties they maintain with state representatives, which ensure that crossing borders will not be too costly, lengthy and risky'. ${ }^{37}$ Networks may serve as forms of positive 'social capital', playing an important role in overcoming transaction costs created by information asymmetries. ${ }^{38}$

\subsection{Winners and losers of pervasive informality}

While the literature has thus explored the factors that may explain the pervasiveness of informality, it also makes clear that different segments of the population are likely to experience informality in diverse ways. Powerful individuals and groups shape the practical norms' defining informal practices and systems of 'real governance', ${ }^{39}$ raising the likelihood that the political economy of informality will be simultaneously exploited (by the powerful) and exploitative (to the vulnerable). While again addressing broader practices of informality, insights from this literature are relevant to understanding the effects and burdens of informal payments within formal cross-border trade. Who bears the heaviest burden - whether economic, social, psychological, or physical - of informal payments? Who is able to use these payments to their advantage?

The most evident possibility is that vulnerable segments of the population may be at a disadvantage within informal transactions and regulatory networks, owing to their lack of negotiating power. In this way informal payments may amount to economic discrimination against vulnerable groups, with small-scale, unorganised or otherwise vulnerable traders shouldering a disproportionate economic burden relative to their income. ${ }^{40}$ In addition to economic discrimination, vulnerable groups, including migrants and women, may also be particularly vulnerable to various forms of harassment by border officials. ${ }^{41}$ However, the literature also points to ways in which the story may be more complex. Research has documented the existence of local moral economies around taxation, which may sometimes provide critical tax exemptions and relief for vulnerable segments of the population, including the disabled or the elderly. ${ }^{42}$ Moreover, the role of collective action is often seen as a way to mediate power differentials: policy-oriented research often calls for the strengthening of informal networks and associations. ${ }^{43}$ However, the reality of organising may be complex in practice. Informal associations may be internally unrepresentative and undemocratic, ${ }^{44}$ while their social and legal marginality and their vulnerability to capture by opportunistic leaders may prevent them from becoming effective local voices. ${ }^{45}$

Existing accounts also make clear that the exercise of power is likely to be mediated through ethnic, social, religious, or kinship networks and personal connections. Just as these networks may shape traders' decisions about whether to engage in informality, research suggests that such networks may also lead to better outcomes in a wide range of public service transactions. ${ }^{46}$ Indeed, because practical norms are often shaped by powerful actors, traders with strong social or identity networks, traders with connections to border officials, or

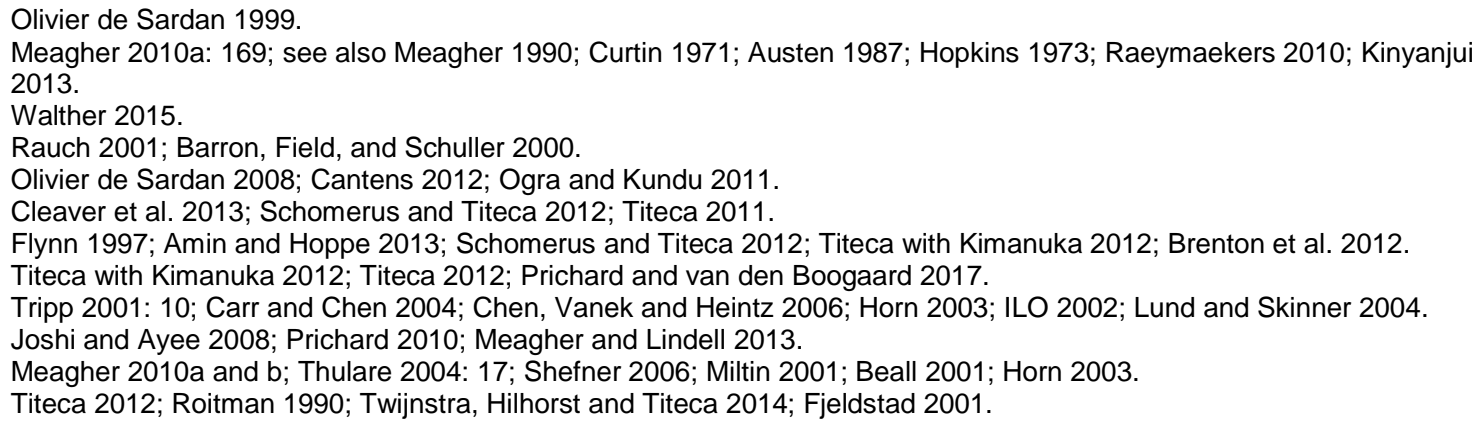


with political or economic influence may be more likely to receive preferential treatment in border transactions. ${ }^{47}$ Correspondingly, certain groups may be particularly disadvantaged by their lack of networks: research suggests that 'outsiders' - be they foreigners or domestic migrants - may be more likely to face harassment or discriminatory tax treatment within border transactions. ${ }^{48}$ This reflects an understanding of the complex nature of networks with respect to informal practices more generally, with social networks either viewed as strengthening flexibility, coordination and economic efficiency in the context of state or market failure ${ }^{49}$ or alternatively as being associated with economic decline and socioeconomic inequality..$^{50}$

\section{The day-to-day reality of cross-border trade in Sierra Leone}

Recorded intra-African trade flows are consistently low, with only about 10 per cent of total African exports and imports accounted for through official intra-African trade. ${ }^{51}$ This situation is reflected in West Africa, despite the Mano River Union and the Economic Community of West African States regional trading agreements.

However, these official statistics are very misleading. As indicated elsewhere, unrecorded trade in West Africa 'vastly exceeds reported bilateral trade'. ${ }^{52}$ Informal, or unrecorded, cross-border trade is prevalent throughout Africa, with important socioeconomic impacts, including income and employment generation. ${ }^{53}$ Since the creation of artificial national boundaries, the border regions of Sierra Leone have been sites of informal trade and activity. Gendema, for instance, is recognised as a 'traditional smuggling centre', indicating a longstanding history of informality in border practices more generally. ${ }^{54}$ The long-term development impact of informality within cross-border trade is also significant, particularly in terms of the losses to national revenue.

Different manifestations of informality are pervasive within the border regions of study. For instance, informal customs clearance agents, known as chata men, serve as important brokers between traders and customs agents in this region of West Africa. ${ }^{55}$ These intermediaries are 'informal' or 'unofficial' insofar as they operate without licences and/or the identification necessary to lodge a declaration. These informal agents are involved in processing documents, negotiating customs rates with border agents, making formal and informal payments to border actors, and/or carrying or driving goods across the border. The complex landscape of cross-border trade also includes other non-state actors who facilitate customs clearance, including drivers and 'loaders'.

\footnotetext{
$47 \quad$ Farré 2013; Twijnstra et al. 2014; Titeca 2012; Raeymaekers 2010; Lourenço-Lindell 2004. This accords with the view of politics and informal institutions in Africa being more personalised than in places with formalised systems of rule what is often referred to as the 'Big Man rule' (Hyden 2012: 97; see also Daloz 2003; Price 1974; Jackson and Rosberg 1982; Lentz 1998).

$48 \quad$ See e.g. Juul 2006; Flynn 1997; Amin and Hoppe 2013; Schomerus and Titeca 2012; Titeca with Kimanuka 2012; Brenton et al. 2012.

$49 \quad$ See e.g. Stiglitz 2000; Powell 1991; Granovetter 1995; MacGaffey 1991; Hansen and Vaa 2004; World Bank 1989; Fafchamps and Minten 1999; Fafchamps 2004.

Castells 1996; Roitman 2004; Chabal and Daloz 1999.

Keane, Calì and Kennan 2010; see also Berg 1985; Yeats 1990.

Golub 2015.

Cantens and Raballand 2017; Amin and Hoppe 2013; Ayadi et al. 2013; Brenton et al. 2012; Golub and Hansen-Lewis 2012; Benjamin et al. 2015; Lesser and Moisé-Leeman 2009; Little 2005; Teka and Azeze 2002; Ndlela 2006; Mijere 2009; Macamo 1999; Ackello-Ogutu and Echessah 1997; MacGaffey 1991; Kabamba 2013; Titeca 2009; Titeca and de Herdt 2010; Roitman 2004; Amin and Hoppe 2013; Igué and Soulé 1992; Azam 2007; Golub 2012; Hashim and Meagher 1999; Galtier and Tassou 1998; Golub and Mbaye 2009; Chalfin 2001; Afrika and Ajumbo 2012; Roitman 2004 Keen 2005: 49 .

55 The use of semi-official intermediaries is common elsewhere. Benjamin and Mbaye 2012.
} 
Adding to this complexity are unofficial customs employees or 'volunteers', who are not welltrained or regulated and who are paid through 'goodwill' payments or other informal tax contributions in a quasi-institutionalised manner. The obvious incentives for informal extraction from traders are amplified by pressures placed on these 'volunteers' by customs officials both at the border posts and at headquarters to remit the 'tips' or 'dash' that are received at the border. Overall, the complexity of this landscape, transposed over numerous layers of security forces, border agents, regulatory agents, and customs officials, offers ample opportunity for private rent seeking. ${ }^{56}$

At the same time, however, we find evidence of informal exemptions being negotiated between customs officials and local communities, in an attempt to balance the dual demands of revenue collection and trade facilitation. Indeed, informally organised joint border management committees, involving traditional authorities, traders, and other stakeholders, have come to informal, ad hoc agreements with border officials to exempt small-scale traders living in the local communities from customs duties for goods staying within the communities. While these goods may be 'duty free', they are not exempt from informal taxes within this broader context of informality, as traders face a range of different payments, constituting a mix of official and unofficial payments that permeate and exist alongside or with the support of formal institutions and practices in an often institutionalised manner. Table 1 reports survey responses about the prevalence of informal payments and practices. Border officials themselves corroborated the prevalence of informal 'taxes'. For instance, one border official explicitly showed us the stacks of bills that were kept in his office for the government, and the stacks that were kept for himself. Another border official noted that, no matter the amount of revenue collected, it would be foolish to give the government revenue in excess of the set targets. Doing so, he claimed, would only lead to an increase in the target, eating away at personal profits.

As elsewhere, the rates of informal taxes are 'partly fixed by precedent and partly negotiated', ${ }^{57}$ and may be made to a range of state and non-state actors stationed at the border and along trade routes, including to customs officers, police or immigration officers, representatives from a range of state ministries and agencies, and unofficial customs employees or 'volunteers'. Direct informal taxes include: 'document acceleration' or 'facilitation' fees, explicitly paid to expedite the customs clearance process, and 'goodwill' payments, otherwise known as 'tips', 'gifts', 'dash', or 'cold water'. The latter differ from acceleration fees as they are not tied to an immediate desired outcome, but are rather used as a means of maintaining strong relationships with border actors and more predictable future outcomes at the border. Border actors may also demand that 'samples' of product/s be given, ostensibly for quality inspection, though often as a form of informal in-kind tax. Traders may pay these informal 'taxes' whether or not they go through formal border channels, pay formal customs duties, or bypass state regulations altogether. ${ }^{58} \mathrm{We}$ consider these payments related to but distinct from corruption, in line with Prud'homme, who defines informal taxation as 'the nonformal means utilised to finance the provision of public goods and services'. ${ }^{59}$ This includes what Prud'homme defines as 'public informal taxation', including 'pinch', as a form of salary supplementation, or 'extortion', both of which may be considered to provide a public good in so far as 'governments provide, at an absolute low point, law and order. Without the means to survive, officials could not perform this duty'. ${ }^{60}$

\footnotetext{
$56 \quad$ Bako-Arifari 2001; Brenton et al. 2012; Titeca with Kimanuka 2012

Golub 2015: 186; see also Titeca with Kimanuka 2012; Roitman 2007; Titeca and Flynn 2014; Reyntjens 2014. Accordingly, we observe how economic activities, actors and payments may exist within both formal and informal realms, reflecting Roitman's (1990: 683, 685) concept of 'straddling' (see also Roitman 2005; Titeca 2012; Titeca with Kimanuka 2012; Titeca and de Herdt 2010; Amin and Hoppe 2013; Ødegaard 2008; Chen 2006; Prag 2013; Meagher 1990; Meagher and Lindell 2013; Cleaver et al. 2013; Cantens, Kaminski, Raballand, and Tchouawou 2014). Prud'homme 1992: 2.

Prud'homme 1992
} 
Finally, the informal negotiation of formal customs rates between frontline customs officials and traders or their representatives (i.e. chata men) is very common. Negotiation generally occurs on a case-by-case basis, though for larger-scale traders in Gbalamuya these negotiations may be more formalised, with minimum duty values set according to the size of the transporting vehicle - though even then traders often reported paying more than prescribed minimums, though less than statutory rates. ${ }^{61}$

Table 2 Prevalence of informal practices

\begin{tabular}{|l|l|l|l|l|l|l|l|}
\hline & $\begin{array}{l}\text { Regular } \\
\text { payment of } \\
\text { document } \\
\text { acceleration } \\
\text { fee }\end{array}$ & $\begin{array}{l}\text { Regular } \\
\text { payment } \\
\text { of } \\
\text { goodwill }\end{array}$ & $\begin{array}{l}\text { Border officials } \\
\text { sometimes or } \\
\text { often request } \\
\text { personal } \\
\text { payments to } \\
\text { have goods } \\
\text { clear customs }\end{array}$ & $\begin{array}{l}\text { Regularly } \\
\text { asked to } \\
\text { give } \\
\text { samples }\end{array}$ & $\begin{array}{l}\text { Regular use } \\
\text { of chata } \\
\text { men }\end{array}$ & \multicolumn{2}{|l|}{$\begin{array}{l}\text { Among those who regularly } \\
\text { pay formal customs rate }\end{array}$} \\
\cline { 5 - 7 } & & $83 \%$ & $56 \%$ & $\begin{array}{l}\text { \% who } \\
\text { regularly } \\
\text { negotiate } \\
\text { the } \\
\text { customs } \\
\text { rate }\end{array}$ & $\begin{array}{l}\text { \% for whom no } \\
\text { receipt is } \\
\text { given/receipt } \\
\text { reflects lower } \\
\text { amount than } \\
\text { that paid }\end{array}$ \\
\hline $\begin{array}{l}\text { All traders } \\
\text { N 197 }\end{array}$ & $35 \%$ & $7 \%$ & $59 \%$ & $61 \%$ & $73 \%$ \\
\hline
\end{tabular}

\section{What explains the prevalence of unrecorded taxation and informal brokerage in cross- border trade?}

Building on the literature and this understanding of the pervasiveness of informal payments and brokerage, we find five central and interconnected explanations as to why traders make informal payments and engage the services of informal brokers when crossing the border.

\subsection{Profit}

First, we explore the idea that traders make informal payments as a means to reduce overall costs and delays. We expect that those who believe that the costs of formal processes are excessively high are more likely to make informal payments or to engage the service of chata men who may be able to negotiate better rates for them. This is supported by descriptive data, as traders identify high formal costs as the dominant motivation for engaging in informal practices, as illustrated in Figure 1. Indeed, the top three reasons that traders gave for hiring chata men to clear customs and for paying 'goodwill', 'tips', or providing product samples to border officials (whether state or non-state actors) are 'to avoid 100 per cent examination', implying higher formal customs duties; 'to avoid delays' at the border; and because formal 'custom rates are too high'. Similarly, the top reasons given for why traders negotiate the formal customs rate was because 'customs rates are too high', 'to avoid 100 per cent examination', and because 'customs rates are set in an unfair or discriminatory manner'.

\footnotetext{
$61 \quad$ Minimum amounts accepted by border officials reportedly ranged from 2 million Sierra Leonean Leones (Le) (US $\$ 462)$ for a six-tyre truck, Le 3 million (US\$693) for a ten-tyre truck, and Le 5 million (US\$1,155) for a twelve-tyre truck. N 178.

N 81.

While 'regularly' is an imprecise measure of frequency, pre-interview training with survey enumerators to ensure consistency of approach and a post-interview focus group discussion with survey enumerators to review our biases leaves us confident that interviewees loosely interpreted 'regularly' to mean 'more often than not' for all relevant survey questions.

65 In line with foundational research in this field (Titeca with Kimanuka 2012), we consider the non-issuance of tax receipts, or the issuance of a receipt reflecting a lower amount than the tax paid, as evidence of informal negotiation or the levying of an informal tax.
} 


\section{Figure 1 Reasons for engaging in informality}

Some traders engage in the following three practices. What do you think are the three main reasons why they adopt these strategies?

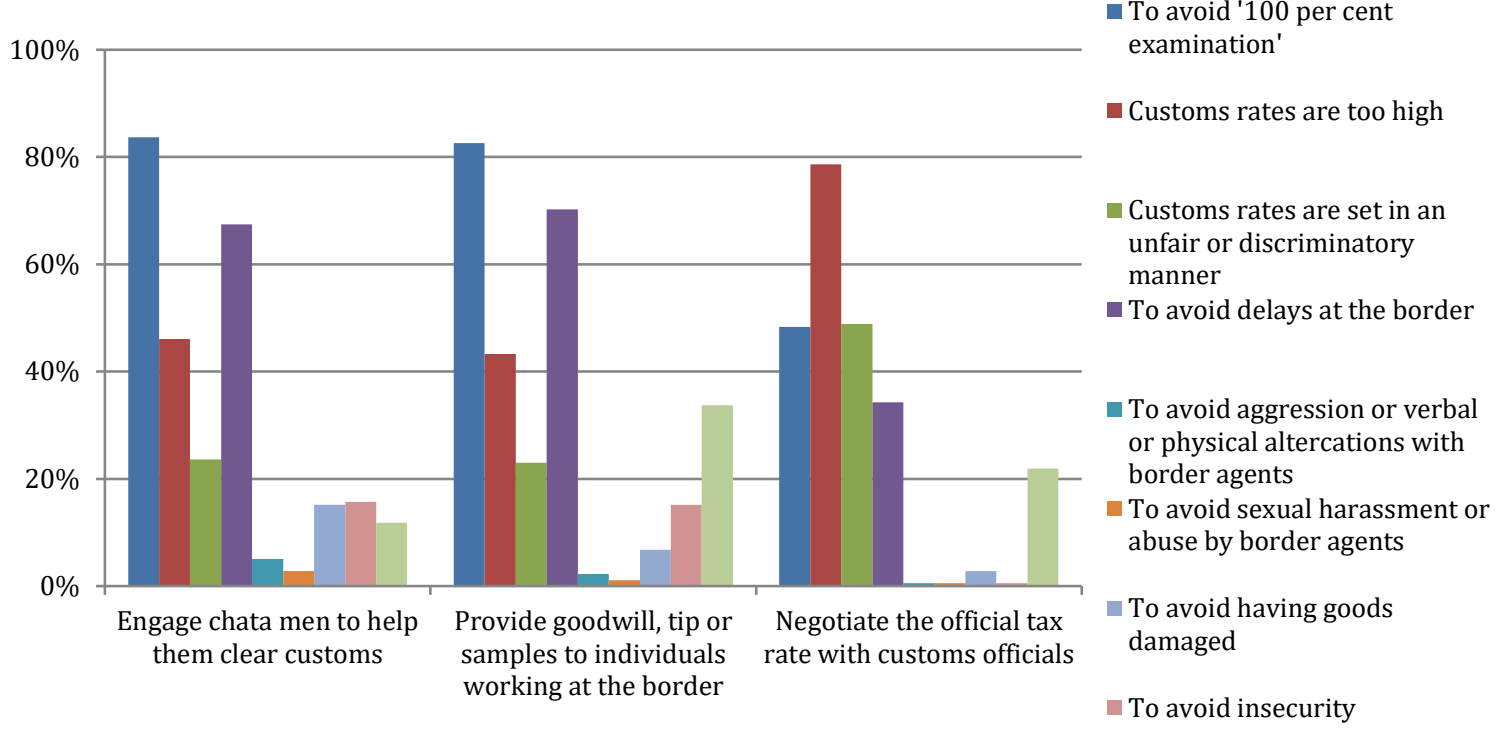

It is the order of the day

Traders themselves reported paying on average 2.7 per cent of the value of the goods they carry across the border in informal payments, while estimating that, if they were to pay official rates, formal payments would amount to an average of 7 per cent of the total value of goods. ${ }^{66}$ Despite the imprecise nature of these self-reported and estimated values, ${ }^{67}$ the overall data is consistent with the notion that, for the average trader, 'savings' on formal rates through the payment of informal taxes, the negotiation of formal rates, or the employment of informal clearing agents to negotiate these rates on their behalf are likely to outweigh the total amount of informal payments made. It is clear, therefore, that both traders and border officials benefit economically from informal payments made through formal border channels.

Our observations at the border posts in question further support the economic rationale for making informal payments. For example, larger traders that are entwined within broader regional trading networks commonly make use of local traders, who benefit from informal exemptions from customs duties, to ferry small numbers of goods across the border. Meanwhile, the direct and indirect costs of formal customs channels are often extremely burdensome given the context. For example, regulatory and documentation requirements (e.g. technical regulations and phytosanitary standards) often require traders, regardless of size, to travel to Freetown to obtain documentation from the only office in the country. From Gendema this is an especially onerous task given the remoteness of the border location and the poor state of the road, which during rainy season is only passable by motorbike. Few

66 The average trader in our sample reports goodwill payments of Le 33,810 (US $\$ 7.81$ ) to multiple actors for every border crossing. In addition to these goodwill payments, traders who regularly give in-kind samples to border officials reported giving an average equivalent value of Le 85,192 (US\$20) per crossing. Traders regularly paying acceleration fees to border officials reported paying an average payment of Le 75,525 (US\$17.45), while chata men reported paying, on average, Le 100,000 (US $\$ 23.10$ ) to 'fast track' document processing. The average value of these payments is calculated as the sum of acceleration fees, goodwill payments, fees for the chata man and the value of samples divided by the value of goods being transported. The latter are recoded in bands, and for this calculation we set the average value of goods being transported to the average value within the band.

67 Ultimately, it is impossible to be certain how much traders 'save' by engaging in informal practices, as compared to formal rates, as traders themselves generally have little understanding of what formal rates should be in individual cases. All of these numbers should be treated as indicative rather than precise: interviews suggest that traders struggle to estimate with any precision the value of the goods being transported, the level of formal rates, or the precise amounts of past informal payments. 
drivers want to cross this challenging terrain so hiring a motorbike is costly, making the journey so expensive as to be prohibitive to most small-scale traders.

Moreover, the use of chata men is at least partially driven by economic incentives, as these brokers are able to fill critical information gaps. As described by Cantens and Raballand, 'Middlemen develop a relationship and negotiation culture with Customs', ${ }^{68}$ providing added value through a capacity to coordinate transactions and minimise transaction costs. ${ }^{69}$ Reflective of information asymmetries at the border, administrative requirements and processes are characterised by opacity, with access to the state limited by linguistic barriers (i.e. forms are written in English), poorly disseminated information about duty rates and trader rights, and low levels of education and confidence amongst traders. All of these factors combine to limit trader willingness to confront or negotiate with border actors and serve as a clear incentive to have a representative act on their behalf. Correspondingly, both traders and chata men described the latter as ensuring lower customs rates and fewer delays because of their knowledge of customs procedures.

\subsection{Power}

Power dynamics also figure centrally in understanding the reasons for making informal payments. We observed power dynamics manifested in different ways at the border posts, with authority wielded by both border officials and informal clearing agents. For instance, information asymmetries are a key source of power within the relationship between traders and informal brokers. As reported elsewhere, these asymmetries can result in misperceptions of the costs and risks of crossing the border. ${ }^{70}$ In our case studies, there is some evidence that chata men deliberately maintain their informational advantage at the border. While chata men have access to the list of formal tariffs, disaggregated by type of goods, this information is not easily accessible for traders. Likewise, there is evidence that attempts to simplify border procedures, such as through the adoption of risk-based assessments for the clearance of goods, ${ }^{71}$ have been limited by political pressures to stall transparency and simplification reform processes. ${ }^{72}$

At the same time, ostentatious displays of wealth (e.g. expensive vehicles) by border officials can reinforce the existing power hierarchy in a context where displays of wealth signal authority and garner respect. These displays and the discretionary distribution of favours to traders create deferential relationships between border officials and traders, and patron-like relationships between high-level border officials and customs 'volunteers', with these volunteers working to extract informal taxes on behalf of their boss, or 'pa'. This leads to situations wherein some border officials are treated with the utmost deference and, in certain observed cases, are even saluted by traders and informal customs employees.

More generally, there is clear evidence that traders - and more vulnerable groups in particular - frequently have little choice in engaging in informal payments and brokerage, and limited leverage in negotiations, while facing high costs for deviating from accepted practices. Traders in focus groups commonly reported believing that they would face strong resistance from border officials and other traders if they were to go against 'the order of the day' of informality - for example, asking for receipts often results in threats of higher payments or unnecessary delays. Likewise, many traders reported that if they didn't use chata men or make informal payments to border actors they would risk having their goods damaged or confiscated or face higher duties. In other instances, border officials create unnecessary delays in order to induce traders to pay acceleration fees or may exploit formal standards

Cantens and Raballand 2017.

Walther 2015, Cantens et al. 2014

Cantens et al. 2014.

Government of the Republic of Sierra Leone (GRSL) 2011.

DFID and Crown Agents 2011. 
and quality requirements in order to extort further informal payments. Chata men also hold power over traders in other ways; for example, chata men themselves reported calling border officials to flag traders who had spurned their services, thereby making them subject to more thorough examinations, delays and higher duties. Nevertheless, one form of coercion may be preferable to the other: indeed, a chata man explained that 'if traders go through customs alone once, they won't want to go through the hassle again', while another chata man described the fear traders have of dealing with customs officials directly. In this way, both border officials and chata men are able to exploit information and power asymmetries. ${ }^{73}$

Given the discretionary nature of these informal practices, we expect that these power dynamics will have disproportionately negative impacts on relatively marginalised populations, who may accordingly be in situations where they have to make informal payments and rely on chata men as a result of their inability to navigate formal processes, or as a result of their vulnerability to predatory extraction by state officials. Indeed, as indicated in Table 2, women are more likely than men to rely on chata men, likely because, as will be discussed below, women are more likely to face verbal, physical and sexual harassment at the border - but not necessarily higher costs.

Table 2 Power and informality

\begin{tabular}{|l|l|l|l|}
\hline & Acceleration fee & Goodwill & Use of chata men \\
\hline Female traders & $35 \%$ & $86 \%$ & $66 \%$ \\
& N 139 & N 142 & N 142 \\
\hline Male traders & $40 \%$ & $75 \%$ & $42 \%$ \\
& N 53 & $\mathrm{~N} 55$ & N 55 \\
\hline
\end{tabular}

\subsection{Networks}

Third, we consider the role of networks and personal relationships in driving informal payments and brokerage. The literature highlights the importance of ethnic, social, religious, and kinship networks in informal cross-border trade and smuggling networks. ${ }^{74}$ Relative to the broader literature on informal cross-border trade, we focus to a greater degree on the personal relationships between border officials and traders, with the understanding that reshaping personal interactions between traders and customs officials - in significant part by reducing the scope of these interactions - has been a key feature of reform efforts for both tax and customs authorities. Indeed, key goals of customs and tax reforms and policies are to minimise personal interactions and individual discretion. This includes ASYCUDA, an automated system that allows data crosschecking in order to reduce the scope of corruption, and the frequent transfer of border officials to different border posts. While broader networks are pivotal in shaping informal cross-border trade more widely, human and relational factors are critical when focusing more specifically on the unrecorded payments that are prevalent within cross-border trade. Due to our narrower focus on unrecorded taxes and informal brokerage, we focus on three elements of the connections that may influence trading behaviour.

First, we look at the place of residence of the traders, with the understanding that border officials, even if they are not from the region, integrate within border communities and engage in the daily life of the area. Second, we look at the frequency with which traders cross the border and thus develop relationships with border officials, and, third, whether traders have an existing personal relationship, whether social, ethnic, religious, or kin-based, with a border official.

\footnotetext{
73 Tegara and Johnson 2007; Titeca with Kimanuka 2012; Cantens 2012.
}

74 See e.g. Meagher 1990; Roitman 1990, 2005; Twijnstra et al. 2014. 
Table 3 Networks and informality

\begin{tabular}{|c|c|c|c|}
\hline . & Acceleration fee & Goodwill & Use of chata men \\
\hline Non-residents of border community & $\begin{array}{l}31 \% \\
\mathrm{~N} 131\end{array}$ & $\begin{array}{l}84 \% \\
\mathrm{~N} 135\end{array}$ & $\begin{array}{l}70 \% \\
\mathrm{~N} 135\end{array}$ \\
\hline Residents of border community & $\begin{array}{l}48 \% \\
\text { N } 61\end{array}$ & $\begin{array}{l}79 \% \\
\text { N } 62\end{array}$ & $\begin{array}{l}35 \% \\
\text { N } 62\end{array}$ \\
\hline $\begin{array}{l}\text { Traders with less frequent border } \\
\text { crossings }^{75}\end{array}$ & $\begin{array}{l}31 \% \\
N 71\end{array}$ & $\begin{array}{l}82 \% \\
N 72\end{array}$ & $\begin{array}{l}61 \% \\
\mathrm{~N} 72\end{array}$ \\
\hline $\begin{array}{l}\text { Traders with more frequent border } \\
\text { crossings }\end{array}$ & $\begin{array}{l}39 \% \\
\text { N } 121\end{array}$ & $\begin{array}{l}83 \% \\
\mathrm{~N} 125\end{array}$ & $\begin{array}{l}58 \% \\
\mathrm{~N} 125\end{array}$ \\
\hline $\begin{array}{l}\text { Traders with no personal relationship with } \\
\text { any border officials }{ }^{76}\end{array}$ & $\begin{array}{l}27 \% \\
\text { N } 59\end{array}$ & $\begin{array}{l}77 \% \\
\text { N } 62\end{array}$ & $\begin{array}{l}71 \% \\
\text { N } 62\end{array}$ \\
\hline $\begin{array}{l}\text { Traders with personal relationship with } \\
\text { one or more border official }\end{array}$ & $\begin{array}{l}41 \% \\
\text { N } 114\end{array}$ & $\begin{array}{l}83 \% \\
\text { N } 116\end{array}$ & $\begin{array}{l}52 \% \\
\text { N } 116\end{array}$ \\
\hline
\end{tabular}

We find that residents of the border communities and those with stronger relationships with border officials are less likely to make use of chata men to cross the border. This corresponds with expectations, given the understanding of intermediaries serving to fill network gaps and navigate local socioeconomies. ${ }^{77}$ Indicating the importance of local networks to navigate informal payments, one chata man explained that he and his colleagues are not required to submit the necessary packing slips for examination and inspection, which would be a 'suicide mission'; instead, 'with the good and longstanding relationships with the inspectors and valuation officers, [we] can skip this process and negotiate duty.' Unsurprisingly, non-residents, more likely to be long distance or regional traders, benefit most from informal brokerage systems.

Interestingly, however, we see that residents of border communities are not significantly less likely to make goodwill payments to border officials, while they are in fact more likely to make acceleration fees or other forms of bribes. This is the case despite the informal duty-free arrangement that has been negotiated by border management communities. Likewise, those with greater familiarity with customs officials, whether through a personal relationship or greater frequency in crossing the border, are in fact more likely to make both acceleration fees and goodwill payments to border officials, contrary to the prediction that such relationships might reduce the need for informal payments. This seeming contradiction may be evidence that those who have stronger relationships with border officials are better able to negotiate directly with them. Indeed, focus group participants consistently reinforced the importance of personal relationships for navigating informal payments and formal customs processes.

However, a full explanation also requires an understanding of the ways in which economic transactions reflect social structures and norms. Indeed, there may be social pressures for traders to engage in informal practices that are beneficial for officials. Likewise, border officials described the necessity of being sympathetic to local conditions, particularly as these are the people that they see in the market and in the course of daily life. Customs officials often explained the negotiation of rates in terms of social obligations to be sympathetic to local economic realities, arguing that statutory customs rates are 'impossible' to apply given local economic conditions, and the awkwardness of applying high formal rates to people within their adopted community. In this way, informal payments may represent a 'moral economy' in that they lessen the overall burden of duties that a trader would face in crossing the border. As described by Cantens and Raballand, 'Customs administrations are flexible

\footnotetext{
75 'Less frequent' defined as less than once a month; 'more frequent' defined as more than once a month.

76 The results here are ordinal, using a measure that ranges from 0-1 based on how many types of customs officials the trader has a relationship with (of the most important state officials at the border: the revenue collector, examination officer, and customs supervisor). Nevertheless, the results are robust to using an alternative binary measure that indicates a relationship with at least one type of customs official (revenue collector, examination officer, or customs supervisor). We also experiment with a measure of familiarity with all border officials (customs officials, as well as police officer, police supervisor, National Revenue Authority Preventative Service and Special Division official) but familiarity with customs officials appears to be most important.

$77 \quad$ Golub 2015; Walther 2015.
} 
and tailor the fiscal burden to make it acceptable to local economic operators. ${ }^{78}$ In addition to these incentives, we also find that personal relationships and the importance of social interactions and norms influence informal payments on both sides: traders may be more willing to provide direct payments to border officials they are familiar with, often describing sympathy for officials whose salaries may be delayed, while customs officials may be more likely to negotiate informally with traders who they have a relationship with or are likely to see around town. Accordingly, informal payments can arise out of 'mutuality and reciprocity of social obligations'. ${ }^{79}$

\subsection{Protest}

Further, traders may make informal payments when they do not trust the state, when they are isolated from the state, or as a form of protest against the state. This may reflect a simple unwillingness to provide revenue to a government that is perceived to be corrupt, or may reflect broader disengagement from the state, with informal practices serving as a form of implicit protest against the state. This may be particularly relevant in Sierra Leone, where communities and chiefdoms in the border areas of Sierra Leone have, as described by Richards, 'a long history of ambiguity about their attachment to state administrative structures', with many having greater faith in chieftaincy institutions and other non-state actors. ${ }^{80}$

While measuring trust in the state is notoriously difficult, we rely on a measure of whether traders are satisfied with a range of public services. ${ }^{81}$ As illustrated by table 4 , we find that traders with greater public service satisfaction are less likely to make informal payments.

\section{Table 4 Correlation between public service satisfaction and informal practices}

\begin{tabular}{|l|l|l|}
\hline & Acceleration fee & Goodwill \\
\hline Public service satisfaction & -0.1083 & -0.0612 \\
\hline
\end{tabular}

We also explore whether informal payments are more common in Gendema, which was aligned with the political opposition at the time of the research, with a population that has a close cultural affinity to groups in neighbouring Liberia. ${ }^{82}$ At the same time, Gendema is comparatively isolated: while the road from Freetown to Gbalamuya is paved and in good condition, the road conditions from Gendema are so poor as to make travel time over even relatively short distances comparatively long, with the roads being virtually impassable during the rainy season (see table 5).

Cantens and Raballand 2017; see also Titeca and Flynn 2014.

Lange 1999.

Richards 1996: 46

'Public service satisfaction' is a composite variable combining trader satisfaction with seven public services at the border: structured marketplace, public security provision, public toilets, road leading to border post, warehousing facility, canopy for examinations, and customs house.

82 For example, the lingua franca is a Liberian dialect of Krio, while traders and business operators prefer to hold Liberian dollars, reflected by a lower black market rate for the Leone relative to the rate in Freetown. 
Table 5 Distances and travel times from border posts ${ }^{83}$

\begin{tabular}{|l|l|l|l|l|l|l|}
\hline & \multicolumn{3}{|c|}{ Gbalamuya } & \multicolumn{2}{c|}{ Gendema } \\
\cline { 2 - 7 } & Distance & $\begin{array}{l}\text { Approximate } \\
\text { travel time for a } \\
\text { truck }\end{array}$ & $\begin{array}{l}\text { Approximate } \\
\text { travel time for a } \\
\text { car }\end{array}$ & Distance & $\begin{array}{l}\text { Approximate } \\
\text { travel time for a } \\
\text { truck }\end{array}$ & $\begin{array}{l}\text { Approximate } \\
\text { travel time for a } \\
\text { car }\end{array}$ \\
\hline Nearest town & $\begin{array}{l}\text { Kambia } \\
11 \mathrm{~km}\end{array}$ & 20 minutes & 20 minutes & $\begin{array}{l}\text { Zimmi } \\
45 \mathrm{~km}\end{array}$ & 3 hours & 2 hours \\
\hline $\begin{array}{l}\text { Nearest } \\
\text { international } \\
\text { airport }\end{array}$ & $\begin{array}{l}\text { Lungi } \\
115 \mathrm{~km}\end{array}$ & 3 hours & 2 hours & $\begin{array}{l}\text { Lungi } \\
426 \mathrm{~km}\end{array}$ & 2 days & 8 hours \\
\hline Nearest port & $\begin{array}{l}\text { Freetown } \\
185 \mathrm{~km}\end{array}$ & 5 hours & 3 hours & $\begin{array}{l}\text { Freetown } \\
386 \mathrm{~km}\end{array}$ & 2 days & 8 hours \\
\hline $\begin{array}{l}\text { Nearest major } \\
\text { market }\end{array}$ & $\begin{array}{l}\text { Port Loko } \\
61 \mathrm{~km}\end{array}$ & 2 hours & 1 hour & $\begin{array}{l}\text { Pujehun } \\
112 \mathrm{~km}\end{array}$ & 1 day & 4 hours \\
\hline
\end{tabular}

As described in Table 6, acceleration fees are much more common in Gendema, though the prevalence of goodwill payments is relatively similar across locations.

Table 6 Prevalence of informal practices by border post

\begin{tabular}{|l|l|l|}
\hline & Acceleration fee & Goodwill \\
\hline Traders in Gbalamuya & $22 \%$ & $84 \%$ \\
& $\mathrm{~N} 97$ & $\mathrm{~N} 101$ \\
\hline Traders in Gendema & $51 \%$ & $81 \%$ \\
& $\mathrm{~N} 95$ & $\mathrm{~N} 96$ \\
\hline
\end{tabular}

Observational evidence supports this finding. The extraction of informal payments was more visible and less discreet in Gendema, with border officials making no effort to disguise negotiations for unrecorded taxes and operating the region as their private fiefdom. Some border officials in Gendema directly related their 'right' to levy informal payments to their feeling of marginalisation from the state. This feeling derived in part from their isolation from major transport routes and the poor condition of the road network, leaving them particularly isolated in rainy season and forced to transport customs revenues to headquarters via long okada (motorcycle taxi) rides. As being posted to a border post like Gendema is often seen as a form of punishment, some border officials expressed their 'right' to collect informal payments as being the least they could expect from the posting in terms of benefits. Further demonstrating their sense of authority in opposition to the state, a border police officer in Gendema related: 'The President may control State House, but we determine what happens here and what we obtain from the post.' Interestingly, then, it is state agents that openly rejected state authority, highlighting the critical difference between the state and its representatives and reinforcing the notion that peripheral regions of the state, including border areas, are often the sites where the realities of state authority and sovereignty are determined. ${ }^{85}$ The border is thus 'a territorial and administrative expression of state sovereignty' where state authority is simultaneously undermined and upheld, ${ }^{86}$ raising 'questions about where the state ends and anti-state resistance begins'. ${ }^{87}$

\subsection{Institutionalisation}

Underpinning these interwoven rationales for making informal payments and using informal brokers is the reality of the normalisation and quasi-institutionalisation of these practices. Forty-seven per cent of traders viewed informal payments favourably. Whether or not traders have positive or negative views of informality has little bearing on the strategies that they adopt. Instead, they appear as a highly normalised set of practices that traders can adopt

\footnotetext{
83 Source: Confluence, WFP

http://dlca.logcluster.org/display/public/DLCA/2.3.4+Sierra+Leone+Border+Crossing+of+Bo-Waterside http://dlca.logcluster.org/display/public/DLCA/2.3.2+Sierra+Leone+Border+Crossing+of+Gbalamuya [both accessed 22 January 2018].

Nearest location with functioning wholesale markets, or with significant manufacturing or production capacity.

See e.g. Lipsky 1983.

Chalfin 2001.

Donnan and Wilson 1999: 106.
} 
and negotiate on a pragmatic basis given their circumstances, 'resources' - often in the form of personal networks - and needs. Even those traders that report dissatisfaction with the current system and mistreatment at the border commonly engage in informal practices as they see no other option. At the same time, certain informal taxes, such as goodwill, are paid on a quasi-automatic basis, with over 80 per cent of traders reporting making these payments on a regular basis. This is consistent with the evidence collected in interviews and focus groups, with respondents viewing goodwill payments as a highly normalised aspect of cross-border trade that is important for maintaining good relations with border officials over time, whether or not traders pay formal customs duties.

The illegality of informal economic practices simply does not have resonance in these areas: many traders expressed a preference for informal practices, while many others failed to recognise these as out of the ordinary, never mind illegal, and certainly not morally wrong. Traders explained that informality has become 'the order of the day' in cross-border trade, while evading official regulations may be seen as legitimate in view of the longstanding cross-border ties of communities. ${ }^{88}$ As Titeca and Flynn explain: 'Legitimacy is a process rather than a fixed reality'. Indeed 'there is a profound difference between norms and rules of formal political authority and how the participants in these transactions perceive these acts' ${ }^{89}$

Aside from this apparent normalisation, the complicity of state representatives at different levels of government provides evidence of the implicit acceptance and quasiinstitutionalisation of informal taxation and brokerage. Anonymous sources in Gbalamuya indicated not only the implicit consent of higher authorities in headquarters, but an expectation of receiving 'brown envelopes' from the informal taxes collected at the border. ${ }^{90}$ At the same time, the informal status of chata men is well known by state representatives, being implicitly accepted as a means of supporting trade flows and ensuring the steady flow of negotiated informal payments. We thus observe 'a complex interplay of formal and informal operators and practices', ${ }^{91}$ which blurs the line of informality and reinforces the notion that 'informality is a continuum rather than a dichotomy'. ${ }^{92}$

\section{Who benefits and who loses from institutionalised informality?}

That the broad contours of the system are widely accepted and normalised does not imply that the impacts of that system will be equitable across different groups. ${ }^{93} \mathrm{We}$ correspondingly implement a regression analysis of our survey data in order to explore the impacts of the described forms of informality in shaping who wins and who loses under existing rules. We consider a range of related outcomes that traders may face in crossing the border: verbal or physical harassment (harassment), sexual harassment (sexual harassment), imprisonment or detention (imprisonment), confiscation of goods (confiscation), damaged goods (damage), and requests for informal payments by border officials (informal payments).${ }^{94}$ We present three primary hypotheses to explain variation in these outcomes.

\footnotetext{
88 This notion of the legitimacy of the evasion of regulations is also described in Flynn 1997: 234; see also Benjamin et al. 2015.

Titeca and Flynn 2014: 73.

Referring to 'brown envelopes' is a local euphemism for accepting bribes or kickbacks.

Golub 2015; Egg and Herrera 1998; Hashim and Meagher 1999.

Benjamin et al. 2015; Benjamin and Mbaye 2012; see also Roitman 2005.

Titeca and de Herdt 2010; Titeca with Kimanuka 2012; Schomerus and Titeca 2012; Tegara and Johnson 2007 ;

Brenton et al. 2012.

We do not include payments as a share of the value of goods being transported owing to two important concerns about data quality. As noted earlier, traders themselves seem to struggle to estimate the value of goods being transported with precision. Second, and more importantly, different types of goods are, in principle, subject to different formal customs rates - and potentially informal rates as well. As such, higher total payments may reflect differences in goods being
} 
Our first hypothesis is that those who are comparatively powerful are likely to experience better treatment at the border. To test this possibility, we identify two groups of comparatively vulnerable traders who we would correspondingly expect to face less positive treatment at the border: female traders (gender) and small-scale traders (size). Table 7 presents descriptive statistics suggesting that women may be subject to greater harassment of different forms and of detention, while small-scale traders may face greater relative financial burdens (e.g. through the confiscation or damage of goods and the request for informal taxes).

Table 7 Social power and treatment at the border

\begin{tabular}{|c|c|c|c|c|c|c|}
\hline $\begin{array}{l}\text { Population sub- } \\
\text { section }\end{array}$ & $\begin{array}{l}\text { Verbal/ } \\
\text { physical } \\
\text { harassment } \\
\text { (N 197) }\end{array}$ & $\begin{array}{l}\text { Sexual } \\
\text { harassment } \\
\text { (N 197) }\end{array}$ & $\begin{array}{l}\text { Imprisonment/ } \\
\text { detainment } \\
\text { (N 197) }\end{array}$ & $\begin{array}{l}\text { Confiscation of } \\
\text { goods } \\
\text { (N 197) }\end{array}$ & $\begin{array}{l}\text { Damaged } \\
\text { goods } \\
\text { (N 178) }\end{array}$ & $\begin{array}{l}\text { Requests } \\
\text { for bribes/ } \\
\text { informal } \\
\text { taxes }{ }^{95} \\
\text { (N 178) }\end{array}$ \\
\hline Female traders & $35.2 \%$ & $23.9 \%$ & $25.4 \%$ & $34.5 \%$ & $50.4 \%$ & $56.1 \%$ \\
\hline Male traders & $12.7 \%$ & $5.5 \%$ & $14.6 \%$ & $41.8 \%$ & $50.9 \%$ & $56.4 \%$ \\
\hline $\begin{array}{l}\text { Small-scale } \\
\text { traders }\end{array}$ & $31.8 \%$ & $13.6 \%$ & $24.2 \%$ & $47.0 \%$ & $57.1 \%$ & $62.5 \%$ \\
\hline $\begin{array}{l}\text { Large-scale } \\
\text { traders }\end{array}$ & $30.7 \%$ & $16.1 \%$ & $19.4 \%$ & $24.2 \%$ & $40.4 \%$ & $49.1 \%$ \\
\hline
\end{tabular}

Our second hypothesis is that those with stronger personal relationships with customs and border agents are likely to experience better treatment at the border. We look at two indicators of the strength of the relationship with border officials: whether traders have a personal relationship with any customs official (familiarity) ${ }^{96}$ and whether they are residents of the border town (border_resident). Table 10 suggests that, in line with expectations, traders that have stronger networks connecting them with customs officials are less likely to face more negative outcomes, while being more likely to face requests for informal taxes. This is in line with the previous discussion, with informal payments forming a part of the personal and social relationships between border officials and traders.

Table 8 Networks and treatment at the border

\begin{tabular}{|l|l|l|l|l|l|l|}
\hline & $\begin{array}{l}\text { Verbal/ } \\
\text { physical } \\
\text { harassment } \\
\text { (N 197) }\end{array}$ & $\begin{array}{l}\text { Sexual } \\
\text { harassment } \\
\text { (N 197) }\end{array}$ & $\begin{array}{l}\text { Detainment } \\
\text { (N 197) }\end{array}$ & $\begin{array}{l}\text { Confiscated } \\
\text { goods } \\
\text { (N 197) }\end{array}$ & $\begin{array}{l}\text { Damaged } \\
\text { goods } \\
\text { (N 178) }\end{array}$ & $\begin{array}{l}\text { Requests } \\
\text { for informal } \\
\text { taxes } \\
\text { (N 178) }\end{array}$ \\
\hline $\begin{array}{l}\text { Traders unfamiliar with } \\
\text { any customs officials }\end{array}$ & $28.9 \%$ & $21.2 \%$ & $19.2 \%$ & $37.5 \%$ & $52.9 \%$ & $52.9 \%$ \\
\hline $\begin{array}{l}\text { Traders familiar with one } \\
\text { or more customs official }\end{array}$ & $22.4 \%$ & $17.6 \%$ & $17.6 \%$ & $39.2 \%$ & $47.3 \%$ & $59.5 \%$ \\
\hline Non-residents & $28.2 \%$ & $23.7 \%$ & $23.0 \%$ & $37.8 \%$ & $54.9 \%$ & $55.7 \%$ \\
\hline Residents of border town & $30.7 \%$ & $8.1 \%$ & $20.97 \%$ & $33.9 \%$ & $41.1 \%$ & $57.1 \%$ \\
\hline
\end{tabular}

Our final hypothesis is that those who are organised into trade associations or other unions are more likely to be targeted at the border, reflecting the possibility that harassment may serve a localised political function, with border officials seeking to assert power over trade associations and civic organizations that are more prone to challenging them. To test these propositions, we consider two variables. First, traders that are members of trade associations, organised to address the issues faced by traders while crossing the border (association), and second, traders who are more directly involved with border issues through involvement with a border management committee (border_management). ${ }^{97}$ Our qualitative

transported, rather than differential treatment - and seeking to account systematically for these differences is not possible given the extent of informality. By contrast, the variables that we include are more unambiguous indications of less favourable treatment.

95 Traders were asked: 'I am now going to list a series of challenges that you may face when crossing the border. For each, please tell me if this never, sometimes or often occurs.' Includes customs revenue collector, customs examination officer and customs supervisor. Involvement includes being an inactive/active member or official leader. Each border management committee has representatives from the community's youth group, women's organisation and other civil society groups, in addition to political and civil servant representatives. 
evidence suggests that these individuals are more likely to express vocal discontent about maltreatment. Table 9 reports descriptive statistics that suggest that members of trade associations and border management committees are consistently more likely to face worse treatment.

Table 9 Control and treatment at the border

\begin{tabular}{|l|l|l|l|l|l|l|}
\hline $\begin{array}{l}\text { Population sub- } \\
\text { section }\end{array}$ & $\begin{array}{l}\text { Verbal/ } \\
\text { physical } \\
\text { harassment } \\
\text { (N 178) }\end{array}$ & $\begin{array}{l}\text { Sexual } \\
\text { harassment } \\
\text { (N 178) }\end{array}$ & $\begin{array}{l}\text { Imprisonment/ } \\
\text { detainment } \\
\text { (N 178) }\end{array}$ & $\begin{array}{l}\text { Confiscation } \\
\text { of goods } \\
\text { (N 178) }\end{array}$ & $\begin{array}{l}\text { Damaged } \\
\text { goods } \\
\text { (N 178) }\end{array}$ & $\begin{array}{l}\text { Requests for } \\
\text { bribes/ } \\
\text { informal taxes } \\
\text { (N 178) }\end{array}$ \\
\hline $\begin{array}{l}\text { Non-members of } \\
\text { trade associations }\end{array}$ & $17.7 \%$ & $12.0 \%$ & $8.2 \%$ & $17.7 \%$ & $36.8 \%$ & $50.6 \%$ \\
\hline $\begin{array}{l}\text { Members of a trade } \\
\text { association }\end{array}$ & $34.3 \%$ & $31.9 \%$ & $35.7 \%$ & $67.6 \%$ & $74.3 \%$ & $75.0 \%$ \\
\hline $\begin{array}{l}\text { Non-members of } \\
\text { border management } \\
\text { committees }\end{array}$ & $22.4 \%$ & $14.4 \%$ & $13.7 \%$ & $23.9 \%$ & $41.7 \%$ & $56.9 \%$ \\
\hline $\begin{array}{l}\text { Members of border } \\
\text { management } \\
\text { committees }\end{array}$ & $31.7 \%$ & $40.0 \%$ & $40.5 \%$ & $85.7 \%$ & $88.1 \%$ & $75.0 \%$ \\
\hline
\end{tabular}

We combine these hypotheses into a multivariate analysis to parse the most important factors shaping outcomes. We employ an ordered logit regression, of the form

Treatment $_{i t}=a+b_{1} *\left(\right.$ Power $\left._{i t}\right)+b_{2} *\left(\right.$ Networks $\left._{i t}\right)+b_{3} *\left(\right.$ Control $\left._{i t}\right)+e_{i t}$

where Treatment refers to the range of challenges or forms of mistreatment in which we are interested, while Power, Networks, and Control are placeholders for the alternative measures of our key hypotheses. ${ }^{98}$ The results of the ordered logit regression are reported in Table 10, while Table 11 reports the marginal effects.

Table 10 Treatment at the border

\begin{tabular}{|c|c|c|c|c|c|c|}
\hline Variables & $\begin{array}{l}\text { (1) } \\
\text { Harassment }\end{array}$ & $\begin{array}{l}(2) \\
\text { Sexual } \\
\text { harassment }\end{array}$ & $\begin{array}{l}\text { (3) } \\
\text { Imprisonment }\end{array}$ & $\begin{array}{l}\text { (4) } \\
\text { Confiscation }\end{array}$ & $\begin{array}{l}\text { (5) } \\
\text { Damage }\end{array}$ & $\begin{array}{l}\text { (6) } \\
\text { Informal payments }\end{array}$ \\
\hline gender & $\begin{array}{l}1.242^{* *} \\
(0.497)\end{array}$ & $\begin{array}{l}1.463^{* *} \\
(0.667)\end{array}$ & $\begin{array}{l}0.241 \\
(0.499)\end{array}$ & $\begin{array}{l}-1.085^{\star \star} \\
(0.455)\end{array}$ & $\begin{array}{l}-0.511 \\
(0.414)\end{array}$ & $\begin{array}{l}0.0816 \\
(0.371)\end{array}$ \\
\hline size & $\begin{array}{l}-0.0275 \\
(0.444)\end{array}$ & $\begin{array}{l}0.780 \\
(0.544)\end{array}$ & $\begin{array}{l}0.0764 \\
(0.502)\end{array}$ & $\begin{array}{l}-0.772^{*} \\
(0.465)\end{array}$ & $\begin{array}{l}-0.326 \\
(0.436)\end{array}$ & $\begin{array}{l}-0.289 \\
(0.396)\end{array}$ \\
\hline familiarity & $\begin{array}{l}-1.797^{\star \star *} \\
(0.616)\end{array}$ & $\begin{array}{l}-1.001 \\
(0.637)\end{array}$ & $\begin{array}{l}-1.098^{*} \\
(0.642)\end{array}$ & $\begin{array}{l}-1.060^{*} \\
(0.559)\end{array}$ & $\begin{array}{l}-1.494^{* * *} \\
(0.505)\end{array}$ & $\begin{array}{l}-0.209 \\
(0.435)\end{array}$ \\
\hline border_resident & $\begin{array}{l}0.572 \\
(0.458)\end{array}$ & $\begin{array}{l}-0.650 \\
(0.587)\end{array}$ & $\begin{array}{l}0.170 \\
(0.500)\end{array}$ & $\begin{array}{l}-0.688 \\
(0.472)\end{array}$ & $\begin{array}{l}-0.782^{*} \\
(0.447)\end{array}$ & $\begin{array}{l}0.0265 \\
(0.397)\end{array}$ \\
\hline association & $\begin{array}{l}0.999^{\star *} \\
(0.471)\end{array}$ & $\begin{array}{c}0.684 \\
(0.534)\end{array}$ & $\begin{array}{l}1.598^{* * *} \\
(0.539)\end{array}$ & $\begin{array}{l}1.665^{\star * *} \\
(0.458)\end{array}$ & $\begin{array}{l}1.008^{\star \star} \\
(0.418)\end{array}$ & $\begin{array}{l}1.033^{* *} \\
(0.426)\end{array}$ \\
\hline border_management & $\begin{array}{l}-0.167 \\
(0.546)\end{array}$ & $\begin{array}{l}1.229^{* *} \\
(0.592)\end{array}$ & $\begin{array}{l}0.610 \\
(0.548)\end{array}$ & $\begin{array}{l}2.268^{* * *} \\
(0.597)\end{array}$ & $\begin{array}{l}2.019^{\star \star * \star} \\
(0.623)\end{array}$ & $\begin{array}{l}0.0548 \\
(0.526)\end{array}$ \\
\hline Constant cut 1 & $\begin{array}{l}2.222^{\star \star \star} \\
(0.628)\end{array}$ & $\begin{array}{l}3.430^{\star \star \star *} \\
(0.866)\end{array}$ & $\begin{array}{l}2.470^{\star \star \star} \\
(0.708)\end{array}$ & $\begin{array}{l}-0.00682 \\
(0.552)\end{array}$ & $\begin{array}{l}-0.568 \\
(0.547)\end{array}$ & $\begin{array}{l}-0.226 \\
(0.492)\end{array}$ \\
\hline Observations & 175 & 172 & 168 & 176 & 169 & 163 \\
\hline
\end{tabular}

Standard errors in parentheses

${ }^{* * *} \mathrm{p}<0.01,{ }^{* *} \mathrm{p}<0.05,{ }^{*} \mathrm{p}<0.1$

$98 \quad$ We also experimented with the inclusion of a variety of alternative control variables but exclude them from the final results as they are rarely significant and have little effect on the final results. In various iterations of this regression, we employed measures of nationality, age, education and political connections, but found they had no significant relationships with treatment at the border. 
Table 11: Marginal effects of independent variables

\begin{tabular}{|c|c|c|c|c|c|c|}
\hline & $(1)$ & (2) & (3) & (4) & (5) & (6) \\
\hline \multirow[t]{2}{*}{ Variables } & Harassment & $\begin{array}{l}\text { Sexual } \\
\text { harassment }\end{array}$ & Imprisonment & Confiscation & Damage & Informal payments \\
\hline & $\mathrm{b} / \mathrm{se}$ & $\mathrm{b} / \mathrm{se}$ & $\mathrm{b} / \mathrm{se}$ & $\mathrm{b} / \mathrm{se}$ & $\mathrm{b} / \mathrm{se}$ & $\mathrm{b} / \mathrm{se}$ \\
\hline \multirow[t]{2}{*}{ gender $(\mathrm{d})$} & $-0.18^{\star \star \star}$ & $-0.15^{\star \star \star}$ & -0.03 & $0.26^{\star *}$ & 0.12 & -0.02 \\
\hline & $(0.06)$ & $(0.05)$ & $(0.06)$ & $(0.11)$ & $(0.10)$ & $(0.09)$ \\
\hline \multirow[t]{2}{*}{ size $(d)$} & 0.00 & -0.09 & -0.01 & $0.18^{*}$ & 0.08 & 0.07 \\
\hline & $(0.07)$ & $(0.05)$ & $(0.06)$ & $(0.11)$ & $(0.10)$ & $(0.09)$ \\
\hline \multirow[t]{2}{*}{ familiarity } & $0.29^{* * *}$ & 0.12 & $0.14^{*}$ & $0.25^{*}$ & $0.37^{\star \star *}$ & 0.05 \\
\hline & $(0.09)$ & $(0.08)$ & $(0.08)$ & $(0.13)$ & $(0.12)$ & $(0.10)$ \\
\hline \multirow[t]{2}{*}{ border_resident (d) } & -0.10 & 0.07 & -0.02 & 0.15 & $0.19^{*}$ & -0.01 \\
\hline & $(0.08)$ & $(0.06)$ & $(0.07)$ & $(0.10)$ & $(0.11)$ & $(0.09)$ \\
\hline \multirow[t]{2}{*}{ association (d) } & $-0.17^{\star *}$ & -0.09 & $-0.23^{\star \star *}$ & $-0.38^{* \star *}$ & $-0.24^{\star *}$ & $-0.23^{\star \star}$ \\
\hline & $(0.08)$ & $(0.07)$ & $(0.08)$ & $(0.10)$ & $(0.10)$ & $(0.09)$ \\
\hline \multirow[t]{2}{*}{ border_management (d) } & 0.03 & $-0.19^{*}$ & -0.09 & $-0.51^{* * *}$ & $-0.41^{\star \star *}$ & -0.01 \\
\hline & $(0.08)$ & (0.11) & $(0.09)$ & $(0.11)$ & $(0.09)$ & $(0.12)$ \\
\hline $\mathrm{N}$ & 175 & 172 & 168 & 176 & 169 & 163 \\
\hline
\end{tabular}

(d) signifies that the independent variable is a binary variable moving from 0 to 1

Three key results emerge from the analysis and are consistent with the discussion so far in emphasising the relative complexity of informal local governance, and the importance of social and political factors in shaping outcomes. First, and somewhat unexpectedly, we find limited evidence that border and customs officials consistently give favour to larger or higher value traders, with evidence only that traders with higher value goods have a marginally reduced risk of having goods confiscated. That said, evidence from our qualitative work suggests that larger traders experience advantages in at least some cases: for instance, container trucks often pay a flat minimum customs rate, regardless of the value of goods on board, which large traders are able to exploit. Moreover, 44 per cent of surveyed traders reported believing that, relative to the average trader, border officials treat traders with more capital or larger businesses more favourably. ${ }^{99}$

The experience of female traders is more complex. On one hand, female traders are subject to greater verbal, physical and sexual harassment, consistent with expectations, previous studies, and our qualitative evidence. On the other hand, however, they are less likely to have their goods confiscated. This is supported by interviews and focus groups, as many respondents reported believing that female traders are treated better. ${ }^{100}$ This is consistent with some other research on the informal sector which found that, in at least some contexts, local moral economies may mitigate against levying higher taxes on women or otherwise treating them poorly, despite their vulnerability in other contexts. ${ }^{101}$ That said, the notion among many traders that women are treated 'better' seems to reflect a primacy given to economic considerations, and the normalisation of other kinds of threats and abuse suffered by female traders.

Second, and consistent with other studies, we again find strong support for the importance of personal relationships in shaping the dynamics of border governance. Those with personal connections or familiarity with customs officials are less likely to face verbal or physical harassment, be detained, or have goods confiscated or damaged. At the same time, residents of border communities are less likely to have their goods damaged when crossing the border. This is consistent with expectations and with our findings about the determinants of informality: the fact that those with personal links to customs officials receive better

\footnotetext{
$99 \quad$ Fifty-two per cent of respondents reported believing the same to be true of local or national elites or 'big men'.

100 Sixty-four per cent of traders reported believing that there was no difference in treatment between male and female traders, while only 9 per cent reported believing that female traders are treated worse than men at the border.

$101 \quad$ Prichard and van den Boogaard 2017.
} 
treatment at the border is consistent with - and, indeed, likely explains - earlier evidence that they are less likely to rely on chata men.

Third, the strongest results point to dramatically greater harassment, instances of detainment, and higher costs (whether through confiscated or damaged goods, or the levying of informal payments) for those who are engaged in civic groups that are related to border outcomes, whether through a trade association or a border management committee. These traders may be known to customs officials because they are involved in collective negotiations; because they are making frequent crossings; or because border communities are usually fairly small. The most compelling interpretation of this finding is that the ability of traders to navigate customs is not just about norms, social networks, and power, but also very much about the logic of control and efforts by frontline officials in border areas to assert their control over potential opponents. Of course, it is possible that this result could be spurious: it may be that those who are more politically active are better informed about their rights and may thus be more likely to see certain actions as harassment or mistreatment relative to other traders. However, both our broader survey and qualitative evidence from interviews corroborate the contention that those who are more politically active suffer greater mistreatment. This underlying reality of unequal power and the potential for coercion is perhaps best reflected in strong evidence that border officials tend to impose significantly higher burdens on those who are mobilised within civic engagement organisations. This is revealed by patterns in our data and is also made explicit in our survey, with 33 per cent of respondents agreeing that: 'It is difficult to form organisations [such as trade associations or unions] at the border, as mobilisation is often perceived as being against the interest of frontline government officials.' The results thus indicate that while trade associations can serve as a means to improve the bargaining position of vulnerable individuals, without a protective enabling environment these networks may also disadvantage traders. It is accordingly unsurprising that other indicators of mobilisation or civic action, including refusing to pay an informal tax to a border official, are close to nil at both border posts. While informality is thus highly normalised and potentially beneficial in reducing costs for some, it is also heavily shaped by (unequally distributed) networks, with those outside of those networks offered few alternatives - and significant potential costs to deviating from established local practices.

\section{Conclusion}

Understanding the determinants and outcomes of informal payments and brokerage in crossborder trade in Sierra Leone cannot simply be explained by rationalist reasoning that focuses on economic motives. Economic motives are a dominant driver of informality overall but are insufficient for explaining specific forms of informality across groups, and the distribution of costs and benefits. Instead, these limited dimensions of informality can only be effectively understood through the complex interplay of profits, power dynamics, personal relationships, protest, the logic of control, and a broader set of norms.

Our research allows us to draw five main conclusions. First, power dynamics and information asymmetries are central to understanding relationships and networks at the border, influencing incentives to engage in informal practices and broadly influencing the winners and losers of cross-border trade. Clearly, strengthening information dissemination strategies with regard to procedures, payments and regulations could have positive implications for treatment of individuals at the border, as well as improving predictability and opportunities for market entry and decreasing opportunities for border actors to extract rents. ${ }^{102}$ Indeed, 86 per cent of traders reported that more public information about assessment and clearing

102 Brenton et al. 2012; Amin and Hoppe 2013. 
procedures would improve their experience of crossing the border. Second, personal relationships are significant to both the incentives to engage in different kinds of informality and the treatment faced by traders at the border, with some evidence of the development of moral economies and mutually beneficial outcomes for border officials and traders. Third, we find that in some cases, state agents engage in informal practices when they feel marginalised from the state. In this way, we see that on-the-ground representatives of the state play a central role in shaping official policy, with implications for state authority and sovereignty. Fourth, we find evidence that border agents use their considerable discretionary power to maintain the status quo in their favour. Finally, social norms and the quasiinstitutionalisation of some informal practices are central to understanding economic interactions and governance within border regions, as well as the perceived legitimacy of such practices. The question for traders thus becomes not whether to engage in informal practices, but what specific informal strategies to adopt given their needs, constraints, and resources. The widespread acceptance of informal payments also raises a set of questions for reformers: how can the benefits of on-the-ground discretion be balanced with the negative outcomes resulting from a lack of oversight or consistency in application? Can the flexibility of informal negotiation - for instance, allowing for exemptions for small-scale traders whose cultural and social lives traverse borders - be formalised in a way that makes these practices more transparently uniform and fair, and less easily exploited? Can informal moral economies be balanced so that they do not simply reflect the 'informalisation of privilege'? ${ }^{103}$

Our initial findings point to the need for deeper exploration of these questions, as well as a deeper exploration of the various indicators found to be significant for understanding the determinants and outcomes of informal payments and brokerage. For instance, while our exploration of personal relationships is important to understanding the psychology and social norms embedded within, and influencing behaviour and treatment in, economic transactions, the analysis would be strengthened by a further exploration of the ethnic, religious, and kinship networks that have been found to be important elsewhere. Moreover, comparatively little is known about the interactions between trade-related associations and border officials. Our evidence suggests that such organisations may hold opportunities for traders but may equally pose risks. Our research points to potential downsides of putting one's head above the parapet, but deeper research is required to better understand the dynamics of this relationship and how negative outcomes may be overcome.

Underpinning these conclusions is a conceptual shift away from a normative understanding of informality as legal or illegal, and towards a perspective that starts from the reality of existing practices and the sociopolitical contexts in which they are embedded, seeking to improve outcomes from that initial foundation. Ultimately, reforms should aim to work 'with the grain' of existing informal economic practices and networks, adapting to an existing context and extending the realm of governance from formal domains of professionalised decision making into everyday economic interactions. ${ }^{104}$

\footnotetext{
103 Portes, Castells and Benton 1989: 289.

$104 \quad$ Booth 2011, Booth 2012, Cleaver et al. 2013.
} 


\section{References}

Ackello-Ogutu, C., and Echessah, P.N. (1998) Unrecorded Cross-Border Trade Between Tanzania and Her Neighbors: Implications for Food Security, Technical Paper No. 89, SD Publication Series, Washington, DC: USAID

(1997) Unrecorded Cross-Border Trade between Kenya and Uganda: Implications for Food Security, Technical Paper No. 59, SD Publication Series, Washington, DC: USAID

Addison, T. and Murshed, S.M. (2001) The Fiscal Dimensions of Conflict and Reconstruction, UNU/WIDER Discussion Paper No. 2001/49

Afrika, J-G. and Ajumbo, G. (2012) Informal Cross-Border Trade in Africa: Implications and Policy Recommendations, Africa Economic Brief 3(10), African Development Bank

Aidt, T.S. (2003) 'Economic Analysis of Corruption: A Survey', The Economic Journal 113(491): 632-652

Aker, J.C., Klein, M.W., O'Connell S.A. and Yang, M. (2014) Borders, Ethnicity and Trade, Journal of Development Economics 107: 1-16

Akinboade, O.A., and Kinfack, E. (2012) 'Regulation, Awareness, Compliance and SME Performance in Cameroon's Manufacturing and Retail Sectors', International Journal of Socio-Economics 39(12): 933-50

Ali, M., Fjeldstad, O-H. and Sjursen, I. (2013) 'Factors Affecting Tax Compliance Attitude in Africa: Evidence from Kenya, Tanzania, Uganda and South Africa', paper presented at Centre for the Study of African Economies (CSAE) Conference, Oxford

Amin, M. and Hoppe, M. (2013) 'Where Informal Procedures Are Quasi-Formal: CrossBorder Trade between West and Central Africa', Policy Note No. 37, Africa Trade Policy Notes, Washington DC: World Bank

Austen, R.A. (1987) African Economic History: Internal Development and External Dependency, London: James Currey

Ayadi, L., Benjamin, N., Bensassi, S. and Raballand, G. (2013) Estimating Informal Trade across Tunisia's Land Borders, Policy Research Working Paper 6731, Washington, DC: World Bank

Azam, J.P. (2007) Trade, Exchange Rate, and Growth in Sub-Saharan Africa, New York: Cambridge University Press

Bako-Arifari, N. (2001) 'La Corruption Au Port de Cotonou: Douaniers et Intermédiaires', Politique Africaine 83: 38-58

Barron, S., Field, J. and Schuller, T. (eds) (2000) Social Capital: Critical Issues, Oxford: Oxford University Press

Beall, J. (2001) 'From Social Networks to Public Action in Urban Governance: Where Does Benefit Accrue?', Journal of International Development 13: 1015-21 
Beck, P. and Maher, M.W. (1986) 'A comparison of bribery and bidding in thin markets', Economic Letters 20: 1-19

Benjamin, N. and Mbaye, A.A. (2012) The Informal Sector in Francophone Africa: Firm Size, Productivity and Institutions, Washington, DC: World Bank

Benjamin, N., Golub, S. and Mbaye, A.A. (2015) 'Informality, Trade Policies and Smuggling in West Africa', Journal of Borderlands Studies, 30(3): 381-394

Berg, E. (1985) Intra-African Trade and Economic Integration, Washington, DC: DAI

Boone, C. (1989) Merchant Capital and the Roots of State Power in Senegal 1930-1985, New York: Cambridge University Press

Booth, D. (2012) Development as a Collective Action Problem: Addressing the Real Challenge of African Governance-Synthesis Report, African Power and Politics Programme, London: Overseas Development Institute (2011) 'Introduction: Working with the Grain: The Africa Power and Politics Programme', IDS Bulletin 42(2): 1-10

Brass, D.J. and Krackhardt, D.M. (2012) 'Power, Politics, and Social Networks in Organizations', in G.R. Ferris and D.C. Treadway (eds) Politics in Organizations: Theory and Research Consideration, New York and London: Routledge: 355-75

Brenton, P., Bashinge Bucekuderhwa, C., Hossein, C., Nagaki, S. and Ntagoma, J-B. (2012) 'Risky Business: Poor Women Cross-Border Traders in the Great Lakes Region of Africa', in P. Brenton and G. Isik (eds), De-Fragmenting Africa: Deepening Regional Trade Integration in Goods and Services, Washington, DC: World Bank

Cantens, T. (2012) Informal Trade Practices, WCO Research Paper No. 22, Brussels: World Customs Organization

Cantens, T. and Raballand, G. (2017) Cross-Border Trade, Insecurity and the Role of Customs: Some Lessons from Six Field Studies in (Post-)Conflict Regions, ICTD Working Paper 67, Brighton: Institute of Development Studies

Cantens, T., Kaminski, J., Raballand, G. and Tchapa, T. (2014) Customs, Brokers, and Informal Sectors: A Cameroon Case Study, Policy Research Working Paper 6788, Washington, DC: World Bank

Carr, M. and Chen, M. (2004) 'Globalization, Social Exclusion and Work: With Special Reference to Informal Employment and Gender', International Labour Review 143: 1-2

Castells, M. (1996) The Rise of the Network Society, Oxford: Blackwell

Chabal, P. and Daloz, J-P. (1999) Africa Works: Disorder as Political Instrument, Indiana: James Currey

Chalfin, B. (2001) 'Border Zone Trade and the Economic Boundaries of the State in NorthEast Ghana', Africa 71(2): 202-24

Chen, M. (2006) 'Rethinking the Informal Economy: Linkages with the Formal Economy and the Formal Regulatory Environment', in B. Guha-Khasnobi, R. Kanbur and E. Orstrom, 
(eds), Linking the Formal and Informal Economy: Concepts and Policies, Oxford: Oxford University Press: 75-92

Chen, M., Vanek, J. and Heintz, J. (2006) 'Informality, Gender and Poverty: A Global Picture', Economic and Political Weekly, May 27, 2131-39

Cleaver, F. (2001) 'Institutional Bricolage, Conflict and Cooperation in Usangu, Tanzania', IDS Bulletin 32(4): 26-35

Cleaver, F., Franks, T., Maganga, F. and Hall, K. (2013) 'Institutions, Security, and Pastoralism: Exploring the Limits of Hybridity', African Studies Review 56(3): 165-89

Cummings, R., Martinez-Vazquez, J., McKee, M. and Torgler, B. (2005) Effects of Tax Morale on Tax Compliance: Experimental and Survey Evidence, CREMA Working Paper Series 2005-29, Center for Research in Economics, Management and the Arts (CREMA)

Curtin, P.D. (1971) 'Pre-Colonial Trading Networks and Traders: The Diakhanke', in C. Meillassoux (ed) The Development of Indigenous Trade and Markets in West Africa, London: Oxford University Press

Daloz, J-P. (2003) "Big Men" in Sub-Saharan Africa: How Elites Accumulate Positions and Resources', Comparative Sociology 2(1): 271-285

de Soto, H. (2000) The Mystery of Capital: Why Capitalism Triumphs in the West and Fails Everywhere Else, New York: Basic Books

(1989) The Other Path: The Invisible Revolution in the Third World, New York: Harper and Row

DFID and Crown Agents (2011) Support to the Sierra Leone National Revenue Authority Phase II, Quarterly Review (December 2010), London: DFID and Crown Agents

Djankov, S., Lieberman, I., Mukherjee, J. and Nenova, T. (2003) 'Going Informal: Benefits and Costs', in B. Belev (ed), The Informal Economy in the EU Access Countries: Size, Scope, Trends and Challenges to the Process of EU Enlargement, Irvine, CA: Center for Study of Democracy: 63-79

Donnan, H. and Wilson, T. (1999) Boundaries of Identity, Nation and State, Oxford: Berg

Dzaka-Kikouta, T. (2004) Focus on Cross-Border Exchanges Between Brazzaville/Congo and Kinshasa/DRC, Paris: Initiative for Central Africa

Egg, J. and Herrera, J. (eds) (1998), Echanges Transfrontaliers et Intégration Régionale en Afrique Subsaharienne, Paris: Orstom

Ellis, S.D.K. and MacGaffey, J. (1996) 'Research on Sub-Saharan Africa's Unrecorded International Trade: Some Methodological and Conceptual Problems', African Studies Review 39(2): 19-41

Fafchamps, M. (2004), Market Institutions in Sub-Saharan Africa, Cambridge, MA: MIT Press

Fafchamps, M. and Minten, B. (1999) 'Relationships and Traders in Madagascar', Journal of Development Studies, 35(6): 1-35 
Farré, A. (2013) 'Informal Cross-Border Trade in Southern Mozambique: Mukhero', paper presented at World Customs Organization Research Conference on Informality, International Trade and Customs, Brussels, 3-4 June 2013

Fjeldstad, O-H. (2004) 'What's Trust Got to do with it? Non-Payment of Service Charges in Local Authorities in South Africa', Journal of Modern African Studies 42(2): 539-562

_ (2001) 'Taxation, Coercion and Donors: Local Government Tax Enforcement in Tanzania', Journal of Modern African Studies 39(2): 289-306

Fjeldstad, O-H. and Semboja, J. (2001) 'Why People Pay Taxes: The Case of the Development Levy in Tanzania', World Development 29(12): 2059-74

Flynn, D. (1997) "We Are the Border": Identity, Exchange, and the State Along the BeninNigeria Border', American Anthropologist 24(3): 311-30

Gajigo, O., and Hallward-Driemeier, M. (2012) Why Do Some Firms Abandon Formality for Informality? Evidence from African Countries, Working Paper Series No. 159, Tunis: African Development Bank

Galtier, F. and Tassou, Z. (1998) 'La Réexportation: Vice ou Vertu? Le Commerce du Bénin vers le Nigeria', in J. Egg and J. Herrera (eds), Echanges Transfrontaliers et Intégration en Afrique Subsaharienne, Paris: Orstrom

Gibson, C. and Hoffman, B. (2005) Fiscal Governance and Public Services: Evidence from Tanzania and Zambia, San Diego: Department of Political Science, University of California, San Diego

Golub, S. (2015) 'Informal Cross-Border Trade and Smuggling in Africa', in O. Morrissey, R. A. López and K. Sharma (eds), Handbook on Trade and Development, Massachusetts, USA: Edward Elgar Publishing

Golub, S. (2012) 'Entrepôt Trade and Smuggling in West Africa: Benin, Togo and Nigeria', The World Economy 35(9): 1139-1161

Golub, S. and Hansen-Lewis, J. (2012) 'Informal Trading Networks in West Africa: The Mourides of Senegal/The Gambia and the Yoruba of Benin/Nigeria', in N. Benjamin and A.A. Mbaye (eds), The Informal Sector in Francophone Africa: Firm Size, Productivity and Institutions, Washington, DC: World Bank

Golub, S. and Mbaye, A.A. (2009) 'National Trade Policies and Smuggling in Africa: The Case of The Gambia and Senegal', World Development 37(3): 595-606

Government of the Republic of Sierra Leone (2011) Report on the Review of the NRA Modernization Project, Freetown: National Revenue Authority, GoRSL

Granovetter, M. (1995) 'The Economic Sociology of Firms and Entrepreneurs', in A. Portes (ed), The Economic Sociology of Immigration: Essays of Ethnic Entrepreneurship, New York: Russell Sage Foundation

Hagmann, T. and Péclard, D. (2010) 'Negotiating Statehood: Dynamics of Power and Domination in Post-Colonial Africa', Development and Change 41(4): 539-62

Hansen, K.T. and Vaa, M. (eds) (2004) Reconsidering Informality: Perspectives from Urban Africa, Uppsala: Nordiska Afrikainstitutet 
Hart, K. (2005) Formal Bureaucracy and the Emergent Forms of the Informal Economy, Research Paper No. 2005/11, UNU-WIDER

Hashim, Y. and Meagher, K. (1999) Cross-Border Trade and the Parallel Currency Market: Trade and Finance in the Context of Structural Adjustment, Research Report No. 113, Uppsala: Nordiska Afrakainstitutet

Hopkins, A.G. (1973) An Economic History of West Africa, London: Longman

Horn, P. (2003) Voice Regulation in the Informal Economy and New Forms of Work, Global Labour Institute

Hyden, G. (2012) African Politics in Comparative Perspective, 2nd ed., Cambridge: Cambridge University Press

Igué, B.O. and Soulé, B. G. (1992), L'Etat Entrepôt au Bénin: Commerce Informel ou Réponse à la Crise? Paris: Karthala

ILO (2002) Decent Work and the Informal Economy, Geneva: International Labour Organization

Jackson, R.H. and Rosberg, C.G. (1982) Personal Rule in Black Africa, Berkeley: University of California Press

Jibao, S. and Prichard, W. (2014) Tax Perceptions in the Periphery: Understanding Tax Compliance in Small Towns in Sierra Leone, ICTD Working Paper, Brighton: Institute of Development Studies

Johnson, S., Kaufmann, D., McMillan, J. and Woodruff, C. (2000) 'Why do Firms Hide? Bribes and Unofficial Activity after Communism', Journal of Public Economics 76(3): 495-520

Joshi, A. and Ayee, J. (2008) 'Associational Taxation: A Pathway into the Informal Sector', in D. Bräutigam, O-H. Fjeldstad, and M. Moore (eds), Taxation and State Building in Developing Countries: Capacity and Consent, Cambridge: Cambridge University Press: 183-211

Juul, K. (2006) 'Decentralization, Local Taxation and Citizenship in Senegal', Development and Change 37(4): 821-46

Kabamba, P. (2013) Business of Civil War: New Forms of Life in the Debris of the Democratic Republic of Congo, Dakar: Codesria

Kanbur, R. (2009) Conceptualising Informality: Regulation and Enforcement, IZA discussion papers, No. 4186, Bonn: IZA

Keane, J., Calì, M. and Kennan, J. (2010) Impediments to Intra-Regional Trade in Sub-

Saharan Africa, ODI Research Report Series, London: Overseas Development Institute

Keen, D. (20015) Conflict and Collusion in Sierra Leone, Suffolk, UK: James Currey

Kinyanjui, M.N. (2013) 'Women Informal Garment Traders in Taveta Road, Nairobi: From the Margins to the Center', African Studies Review 56(3): 147-164 
Klein, A. (1999) 'The Barracuda's Tale: Trawlers, the Informal Sector and a State of Classificatory Disorder of the Nigeria Coast', Africa 69(4): 555-74

Klitgaard, R. (1988) Controlling Corruption, Berkeley: University of California Press

Lange, B. (1999) 'Compliance Construction in the Context of Environmental Regulation', Social and Legal Studies 8(4): 549-67

La Porta, R. and Shleifer, A. (2014) 'Informality and Development', unpublished paper

Leff, N. (1964) 'Economic development through bureaucratic corruption', American Behavioral Scientist 8(3): 8-14

Lentz, C. (1998) 'The Chief, the Mine Captain and the Politician: Legitimating Power in Northern Ghana', Africa 68(1): 46-67

Lesser, C. and Moisé-Leeman, E. (2009) Informal Cross-Border Trade and Trade Facilitation Reform in Sub-Saharan Africa, OECD Trade Policy Working Paper No. 86, Paris: OECD

Levin, J. and Widell, L. (2007) Tax Evasion in Kenya and Tanzania: Evidence from Missing Imports, Working Paper No. 8, Department of Business, Economics, Statistics and Informatics, Orebro, Sweden: University of Orebro

Levy, S. (2008) Good Intentions, Bad Outcomes: Social Policy, Informality, and Economic Growth in Mexico, Washington, DC: Brookings Institution

Lipsky, M. (1983) Street-Level Bureaucracy: Dilemmas of the Individual in Public Services, New York: Russell Sage Foundation

Little, P.D. (2005) Unofficial Trade When States are Weak: The Case of Cross Border Commerce in the Horn of Africa, WIDER Research Paper No. 2005/13, Helsinki: WIDER

Loayza, N.V., Oviedo, A.M. and Serven, L. (2005) The Impact of Regulation, Growth and Informality - Cross-Country Evidence, Policy Research Working Paper 3623, Washington, DC: World Bank

Lourenço-Lindell, I. (2004) 'Trade and the Politics of Informalization in Bissau, GuineaBissau', in K. Tranberg Hansen and M. Vaa (eds) Reconsidering Informality: Perspectives from Urban Africa, Uppsala, Sweden: Nordiska Afrikainstitutet

Lui, F.T. (1985) 'An Equilibrium Queuing Model of Bribery', Journal of Political Economy 93: $760-781$

Lund, C. (2006) 'Twilight Institutions: Public Authority and Local Politics in Africa', Development and Change 37(4): 685-705

Lund, F. and Skinner, C. (2004) 'Integrating the Informal Economy in Urban Planning and Governance: A Case Study of the Process of Policy Development in Durban, South Africa', International Development Planning Review 26 (4)

Macamo, J. L. (1999) Estimates of Unrecorded Cross-Border Trade Between Mozambique and Her Neighbors, Technical Paper No. 88, SD Publication Series, Washington, DC: USAID 
MacGaffey, J. (ed) (1991) The Real Economy of Zaire: The Contribution of Smuggling \& Other Unofficial Activities to National Wealth, London: James Currey

Mahmood, H.A. (2008), 'Risky Trade, Resilient Traders: Trust and Livestock Marketing in Northern Kenya', Africa, 78(4): 561-81

Meagher, K. (2013) 'Informality, Religious Conflict, and Governance in Northern Nigeria: Economic Inclusion in Divided Societies', African Studies Review 56(3): 209-34

(2012) 'The Strength of Weak States? Non-State Security Forces and Hybrid Governance in Africa', Development and Change 43(5)

(2011) 'Informal Economies and Urban Governance in Nigeria: Popular

Empowerment or Political Exclusion?', African Studies Review 54(2): 47-72

(2010a) Identity Economics. Social Networks and the Informal Economy in Nigeria, Oxford: James Currey

(2010b) 'The Politics of Vulnerability: Exit, Voice and Capture and the Three Nigerian Informal Manufacturing Clusters', in I. Lindell (ed), Africa's Informal Workers: Collective Agency, Alliances and Transnational Organizing, London: Zed Books

(2008) 'Informality Matters: Popular Economic Governance and Institutional Exclusion in Nigeria', paper presented at St Antony's College, Oxford, January 11-12

_ (2007) 'Introduction: Special Issue on "Informal Institutions and Development in Africa"', Afrika Spectrum 42 (3): 405-18

(2005) 'Social Capital or Analytical Liability? Social Networks and African Informal Economies', Global Networks 5(3): 217-38

(1990) 'The Hidden Economy: Informal and Parallel Trade in Northwestern Uganda', Review of African Political Economy 47: 64-83

Meagher, K. and Lindell, I. (2013) 'Introduction: Engaging with African Informal Economies: Social Inclusion or Adverse Incorporation?', African Studies Review 56(3): 57-76

Médard, J-F. (2002) 'Corruption in the Neo-Patrimonial States of Sub-Saharan Africa, in A.J. Heidenheimer and M. Johnston (eds), Political Corruption: Concepts and Contexts, 3rd edition, New Jersey: Transaction Publishers: 379-402

Migdal, J. and Schlichte, K. (2005) 'Re-thinking the State', in K. Schlichte (ed), The Dynamics of States: The Formation and Crises of State Domination, Burlington, Vt: Ashgate: 1-40

Mijere, N.J.N. (2009) Informal Cross Border Trade in the Southern African Development Community (SADC), Addis Ababa: Organization for Social Science Research in Eastern and Southern Africa

Miltin, D. (2001) 'The Formal and Informal Worlds of State and Civil Society: What Do They Offer to the Urban Power?', International Planning Studies 6(4): 377-92

Minde, I.J., and Nakhumwa, T.O. (1998) Unrecorded Cross-Border Trade Between Malawi and Neighboring Countries, Technical Paper No. 90, SD Publication Series, Washington, DC: USAID 
Morini, C. (2013) 'Fifteen Dimensions of Informality in the Brazilian Foreign Trade', paper presented at World Customs Organization Research Conference on Informality, International Trade and Customs, Brussels, 3-4 June 2013

Muwulya, G. (2013) 'The Nature of Informal Cross-Border Trade in Uganda, its Justifications, Effects, and How Customs Administration Handles it', paper presented at the World Customs Organization Research Conference on Informality, International Trade and Customs, Brussels, 3-4 June 2013

Ndlela, D.B. (2006) Informal Cross-Border Trade: The Case of Zimbabwe, Occasional Paper No. 52, Johannesburg: Institute for Global Dialogue

Ødegaard, C. (2008) 'Informal Trade, Contrabando and Prosperous Socialities in Arequipa, Peru', Ethnos 73(2): 241-66

OECD (2002) Business Benefits of Trade Facilitation, TD/TC/WP (2001)21/FINAL, Paris: OECD

Ogra, A. and Kundu, D. (2011) 'Local Taxation of Informal Economies: A Case Study of Two Indian States', in N. Devas (ed), Local Taxation and Informal Economies, Budapest: Local Government and Public Sector Reform Initiative of the Open Society Foundation: $17-62$

Olivier de Sardan, J-P. (2008) Researching the Practical Norms of Real Governance in Africa, Africa Power and Politics Discussion Paper No. 5, London: Overseas Development Institute (1999) 'A Moral Economy of Corruption in Africa?', The Journal of Modern African Studies 37(1): 25-52

Oyejide, T., Ademola, E., Ogunkola, O., Bankole, A.S. and Adwuyi, O.A. (2008) Study of Trade Policy and Nigerian Wholesale Prices, Report prepared for the World Bank, Washington, DC: World Bank

Perry, G., Maloney, W., Arias, O., Fajnzylber, P., Mason, M. and Saavedra, J. (2007) Informality: Exit and Exclusion, World Bank Latin America and Caribbean Studies, Washington, DC: World Bank, 2007

Popkin, S. L. (1979) The Rational Peasant: The Political Economy of Rural Society in Vietnam, Berkeley and Los Angeles: University of California Press

Portes, A. (1994) 'The Informal Economy and Its Paradoxes', in N. Smelser and R. Swedberg (eds), The Handbook of Economic Sociology, New Jersey: Princeton University Press: 426-448

Portes, A., Castells, M. and Benton, L.A. (1989) The Informal Economy: Studies in Advanced and Less Developed Countries, Baltimore: Johns Hopkins University Press

Powell, W.W. (1991) 'Neither Market nor Hierarchy: Network Forms of Organization, in G. Thompson, J. Frances, R. Levacic and J. Mitchell (eds), Markets, Hierarchies and Networks: The Coordination of Social Life, London: Sage: 265-76

Prag, E. (2013) 'Mama Benz in Trouble: Networks, the State, and Fashion Wars in the Beninese Textile Market', African Studies Review 56(3): 101-21 
Price, R. (1974). 'Politics and Culture in Contemporary Ghana: The Big Man, Small-Boy Syndrome', Journal of African Studies 1(2): 173-204

Prichard, W. (2010) Taxation and State Building: Towards a Governance Focused Tax Reform Agenda, IDS Working Paper 341, Brighton: Institute of Development Studies

Prichard, W. and van den Boogaard, V. (2017) 'Norms, Power and the Socially Embedded Realities of Market Taxation in Northern Ghana', African Studies Review 60 (1): 171194

Prud'homme, R. (1992) 'Informal Local Taxation in Developing Countries', Environment and Planning C: Government and Policy 10: 1-17

Raeymaekers, T. (2014) Violent Capitalism and Hybrid Identity in the Eastern Congo: Power to the Margins, New York: Cambridge University Press

(2010) 'Protection for Sale? War and the Transformation of Regulation on the CongoUgandan Border', Development and Change 41(4): 563- 587

Rauch, J. E. (2001) 'Business and Social Networks in International Trade', Journal of Economic Literature, 49(4): 1177-203

Reyntjens, F. (2014) 'Regulation, Taxation and Violence: The State, Quasi-State Governance and Cross-Border Dynamics in the Great Lakes Region', Review of African Political Economy 41(142): 530-44

Richards, P. (1996) Fighting for the Rain Forest: War, Youth and Resources in Sierra Leone, Oxford: James Currey

Roitman, J. (2007) 'The Right to Tax: Economic Citizenship in the Chad Basin', Citizenship Studies 11(2): 187-209

_ (2005) Fiscal Disobedience. An Anthropology of Economic Regulation in Central Africa, Princeton: Princeton University Press

(2004) 'Power Is Not Sovereign: The Pluralisation of Economic Regulatory Authority in the Chad Basin', in B. Hibou (ed), Privatising the State, London: Hurst: 120-146

(1990) 'The Politics of the Informal Markets in Sub-Saharan Africa', Journal of Modern African Studies 28(4): 671-96

Schomerus, M., and Titeca, K. (2012) 'Deals and Dealings: Inconclusive Peace and Treacherous Trade along the South Sudan-Uganda Border', Africa Spectrum 47(2-3): 5-31

Scott, J. (1985) Weapons of the Weak: Everyday Forms of Peasant Resistance, New Haven: Yale University Press

Shefner, J. (2006) 'Do You Think Democracy is a Magical Thing? From Basic Needs to Democratization in Informal Politics', in P. Fernandez-Kelly and J. Shefner (eds), Out of the Shadows: Political Action and the Informal Economy in Latin America, Pennsylvania: Pennsylvania State University Press: 241-67 
Sindzingre, A. (2002) 'A Comparative Analysis of African and East Asian Corruption', in A.J. Heidenheimer and M. Johnston (eds), Political Corruption: Concepts and Contexts, 3rd ed., New Jersey: Transaction Publishers: 441-462

Smart, A. (2013) 'Customs Control over Illicit International Trade: The Impact of Different Forms of Illegality', paper presented at the World Customs Organization Conference on Informality, International Trade and Customs, Brussels, 3-4 June 2013

Stiglitz, J.E. (2000) 'Formal and Informal Institutions', in P. Dasgupta and I. Serageldin (eds), Social Capital: A Multifaceted Perspective, Washington DC: World Bank: 59-68

Tegera, A., and Johnson, D. (2007) 'Rules for Sale: Formal and Informal Cross-Border Trade in Eastern DRC', Regards Croises 19

Teka, T. and Azeze, A. (2002) Cross-Border Trade and Food Security in the EthiopiaDjibouti and Ethiopia-Somalia Borderlands, OSSREA Development Research Report Series No. 4, Addis Ababa, Ethiopia: OSSREA

Thulare, P. (2004) Trading Democracy? Johannesburg Informal Traders and Citizenship, Policy: Issues \& Actors 17(1), Johannesburg: Centre for Policy Studies

Titeca, K. (2012) 'Tycoons and Contraband: Informal Cross-Border Trade in North-Western Uganda', Journal of Eastern African Studies 6(1): 47-63

(2011) 'Access to Resources and Predictability in Armed Rebellion: The FAPC's Short-Lived 'Monaco' in Eastern Congo', Africa Spectrum 46(2): 43-70

- (2009) The Changing Cross-border Trade Dynamics between North-Western Uganda, North-Eastern Congo and Southern Sudan, Crisis States Research Centre Working Paper No. 63, London: Crisis States Research Centre

Titeca, K., and De Herdt, T. (2011) 'Real Governance Beyond the "Failed State": Negotiating Education in the Democratic Republic of the Congo', African Affairs 110(439): 213-231

(2010) 'Regulation, Cross-Border Trade and Practical Norms in West Nile, NorthWestern Uganda', Africa 80(4): 573-94

Titeca, K., with Kimanuka, C. (2012) Walking in the Dark: Informal Cross-Border Trade in the Great Lakes Region, International Alert and UN Women

Titeca, K. and Flynn, R. (2014) "'Hybrid Governance”, Legitimacy, and (II)legality in the Informal Cross-Border Trade in Panyimur, Northwest Uganda, African Studies Review 57(1): 71-91

Torgler, B. (2004) Tax Morale, Trust and Corruption: Empirical Evidence from Transition Countries, Working Paper 2004: 5, Basel: Center for Research in Economics, Management and the Arts

Tripp, A.M. (2001) Non-Formal Institutions, Informal Economies, and the Politics of Inclusion, Discussion Paper No. 2001/108, UNU/WIDER

Twijnstra, R., Hilhorst, D. and Titeca, K. (2014) 'Trade Networks and the Practical Norms of Taxation at a Border Crossing between South Sudan and Northern Uganda', Journal of Eastern African Studies, 1-18 
Walther, O. J. (2015) 'Business, Brokers, and Borders: The Structure of West African Trade Networks', Journal of Development Studies 51(5): 603-20

Waseem, M. (2013) Taxes, Informality and Income Shifting: Evidence from a Recent Pakistani Tax Reform, LSE Working Paper Series, London, UK: London School of Economics

World Bank (1989) Sub-Saharan Africa: From Crisis to Sustainable Growth, Washington, DC: World Bank

Yeats, A.J. (1990) 'On the Accuracy of Economic Observations: Do Sub-Saharan Trade Statistics Mean Anything?', World Bank Economic Review, 4(2): 135-56

Yoshino, Y. Ngungi, G. and Asebe, E. (2012) 'Enhancing the Recent Growth of Cross-Border Trade between South Sudan and Uganda', in P. Brenton and G. Isik (eds), Defragmenting Africa: Deepening Regional Trade Integration in Goods and Services, Washington, DC: World Bank

Young, C. (1994) The African Colonial State in Comparative Perspective, New Haven: Yale University Press 